Article

\title{
Structural Setting of the Sixtymile Gold District, Yukon, Canada: Insights into Regional Deformation and Mineralization from Field Mapping and 3D Magnetic Inversion
}

\author{
Jeremy Rimando ${ }^{1, * \mathbb{D}}$, Alexander L. Peace ${ }^{1} \mathbb{D}$, Meixia Geng ${ }^{2} \mathbb{D}$, Jacob Verbaas ${ }^{3}$ and Harley Slade $^{3} \mathbb{D}$ \\ 1 School of Earth, Environment and Society, McMaster University, Hamilton, ON L8S 4K1, Canada; \\ peacea2@mcmaster.ca \\ 2 Department of Earth Sciences, Khalifa University of Science and Technology, \\ Abu Dhabi P.O. Box 127788, United Arab Emirates; gengmeixia@126.com \\ 3 Flow Metals Corporation, Vancouver, BC V6E 3V6, Canada; jacobverbaas@gmail.com (J.V.); \\ cavemanexploration@gmail.com (H.S.) \\ * Correspondence: rimandoj@mcmaster.ca
}

check for

updates

Citation: Rimando, J.; Peace, A.L.;

Geng, M.; Verbaas, J.; Slade, H.

Structural Setting of the Sixtymile Gold District, Yukon, Canada: Insights into Regional Deformation and Mineralization from Field

Mapping and 3D Magnetic Inversion. Minerals 2022, 12, 291. https:// doi.org/10.3390/min12030291

Academic Editors: Huan Li, Han Zheng and Yosoon Choi

Received: 8 December 2021 Accepted: 23 February 2022 Published: 25 February 2022

Publisher's Note: MDPI stays neutral with regard to jurisdictional claims in published maps and institutional affiliations.

Copyright: (c) 2022 by the authors. Licensee MDPI, Basel, Switzerland. This article is an open access article distributed under the terms and conditions of the Creative Commons Attribution (CC BY) license (https:// creativecommons.org/licenses/by/ $4.0 /)$.

\begin{abstract}
The Sixtymile gold district, Yukon, Canada has been mined for placer gold since the late 19th century. However, increasing demand for gold has prompted exploration of new lode deposits. Previous studies in the nearby Klondike gold district have shown correlation between placer deposits and bedrock occurrences. Poor bedrock exposure and a complex deformation history, however, make it difficult to determine structural controls on gold mineralization. Through structural analysis involving mesoscopic-scale field observations of fractures, faults, foliation, and folds, and 3D geophysical inversion, the goal of this study was to determine the structural setting of the Sixtymile district to enhance discovery success. Structural measurements in the Glacier Creek, Miller Creek, Bedrock Creek, and Sixtymile River areas show the relationships among the orientations of foliation, fractures, and veins. In most localities, veins are found both parallel and at high angles to foliation, and there is generally a weaker correlation between fractures and veins compared to between foliation and veins. This correlation between foliation and veins is corroborated by inferred gold-bearing horizons from gold assay data. Outcrops of oblique reverse and strike-slip faults, possibly related to a larger-scale thrust-zone, and to the left-lateral Sixtymile-Pika Fault, respectively, were documented for the first time in this study. The results of the 3D probabilistic inversion of total magnetic intensity data for magnetic susceptibility show that magnetic susceptibility highs are preferentially associated with volcanics, but also point to possible intrusive bodies or hydrothermal alteration zones associated with mineralization. A geologic cross-section through the lithologies demonstrates highly variable deformation styles, including extensive folding, possibly indicative of a multiphase deformational history necessitating further, more detailed investigations of the area.
\end{abstract}

Keywords: Sixtymile gold district; structural controls; 3D magnetic susceptibility

\section{Introduction}

The Sixtymile mining district in the Yukon Territory, Canada is located in the Sixtymile River watershed which is $\sim 75 \mathrm{~km}$ west of Dawson City and $\sim 10 \mathrm{~km}$ east of the border with Alaska, USA (Figure 1). Since the late 19th century, it has been known primarily for its placer gold deposits, and is proximal to the Klondike Mining district- the site of the famous Klondike Gold Rush. The main streams that were mined in the district are the Bedrock, Big Gold, Little Gold, Glacier, and Miller [1] (Figure 2). Combined, these creeks likely produced $>400,000$ ounces of gold from 1892-2005 [2]. Placer gold deposits in this mining district, and in the vicinity, occur both in low-level creek gravels (valley bottoms), and in low- and high-level terraces (resting on schist bedrock) that were mainly formed by 
aggradation and incision associated with phases of glaciation and deglaciation in the past $\sim 40 \mathrm{ka}[3,4]$.

The interpreted bedrock sources for gold in the region are Jurassic orogenic (mesothermal) gold deposits hosted in uplifted and exhumed greenschist facies rocks [5]. Prospectors have historically taken advantage of the proximity between exposed bedrock occurrences and placer deposits for their investigations on the location of orogenic veins $[6,7]$.

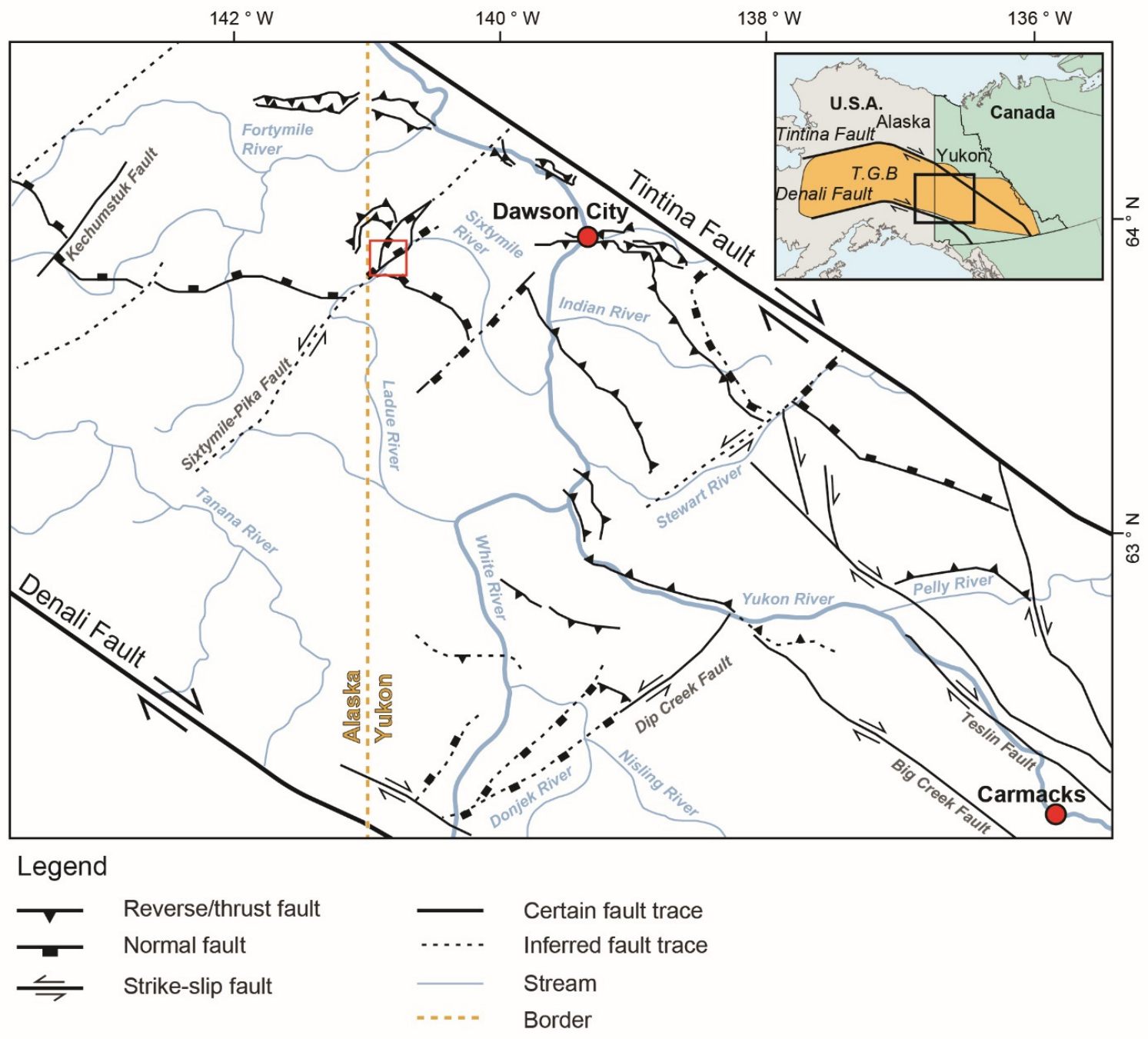

Figure 1. Regional structures in the Alaska-Yukon region (modified after Allan et al., 2013) [8]. Inset map shows the location of the Tintina Gold Belt (T.G.B.). The study area (red box) is located close to the Alaska-Yukon border and lies within an area interpreted as a pull-apart basin resulting from left stepover on the left-lateral Sixtymile-Pika Fault.

However, almost 120 years since the Yukon placer gold rush, little is known about the structural setting of bedrock gold occurrence in the region $[5,9,10]$. A recent increase in demand for gold has prompted the exploration of new minable placer gold deposit sites and lode deposits [11]. Yet, there has only been small, incremental progress in bedrock mining due to the poor exposures, and consequently, insufficient knowledge of the bedrock geology [12]. In the main Klondike Gold district, placer gold has been suggested by geochemical signatures and microchemical characterizations to originate from a local bedrock source, and that these sources are associated with intrusions and/or hydrothermal/epithermal auriferous quartz veins within the underlying Klondike Schist [13-15]. 
As previous studies in nearby gold mining districts suggest, and as would be expected of orogenic gold deposits, orogenic veins in the region should be structurally controlled [5]. While it has been hypothesized that the gold-bearing faults may be correlated with planform geometry of drainage systems [12], the complexly deformed schists, which resulted from several brittle and ductile deformation phases that involved the reactivation and overprinting of fold-fault structures [16], makes it challenging to properly identify and map out important gold-bearing structures. Moreover, the dense vegetative cover on the colluvium-draped hillslopes and the reworking by permafrost processes makes good basement rock exposures rare [17].

Despite the inferred sufficiently high concentration of coarse lode gold mineralization that is responsible for the rich placer deposits in the Sixtymile district [18], there is little information on the local and regional structural setting of this mining district that could be useful for targeting structures associated with lode gold-bearing veins.

As such, the aim of this study was to document the outcrop- to regional-scale structures in the Sixtymile area to gain a better understanding of the structural controls of mineralization that can facilitate future exploration work, not only at Sixtymile, but more widely in the Klondike region. This was achieved through a combined approach utilizing geological field mapping and the 3D inversion of magnetic intensity data. While inversion of potential-field geophysical data sets has previously been applied to map subsurface structures in the Yukon, these have been performed mostly on lithospheric-scale structures such as the Tintina Fault [19-21]. In addition, although detailed lineament mapping of local structures exists (e.g., Sixtymile-Pika Fault Zone) [22,23], there is a lack of well-documented ground truthing of structural interpretations that can be considered in designing efficient exploration programs.

This study applied an integrated field-based geological and 3D geophysical inverse modeling approach to provide insights into the structural setting and geological evolution of the area, to interpret the complex ore-bearing structural geometries and lithological distributions at depth (and their associated geophysical signatures) with higher accuracy, so as to reduce mineral exploration risk, and to highlight new opportunities. 


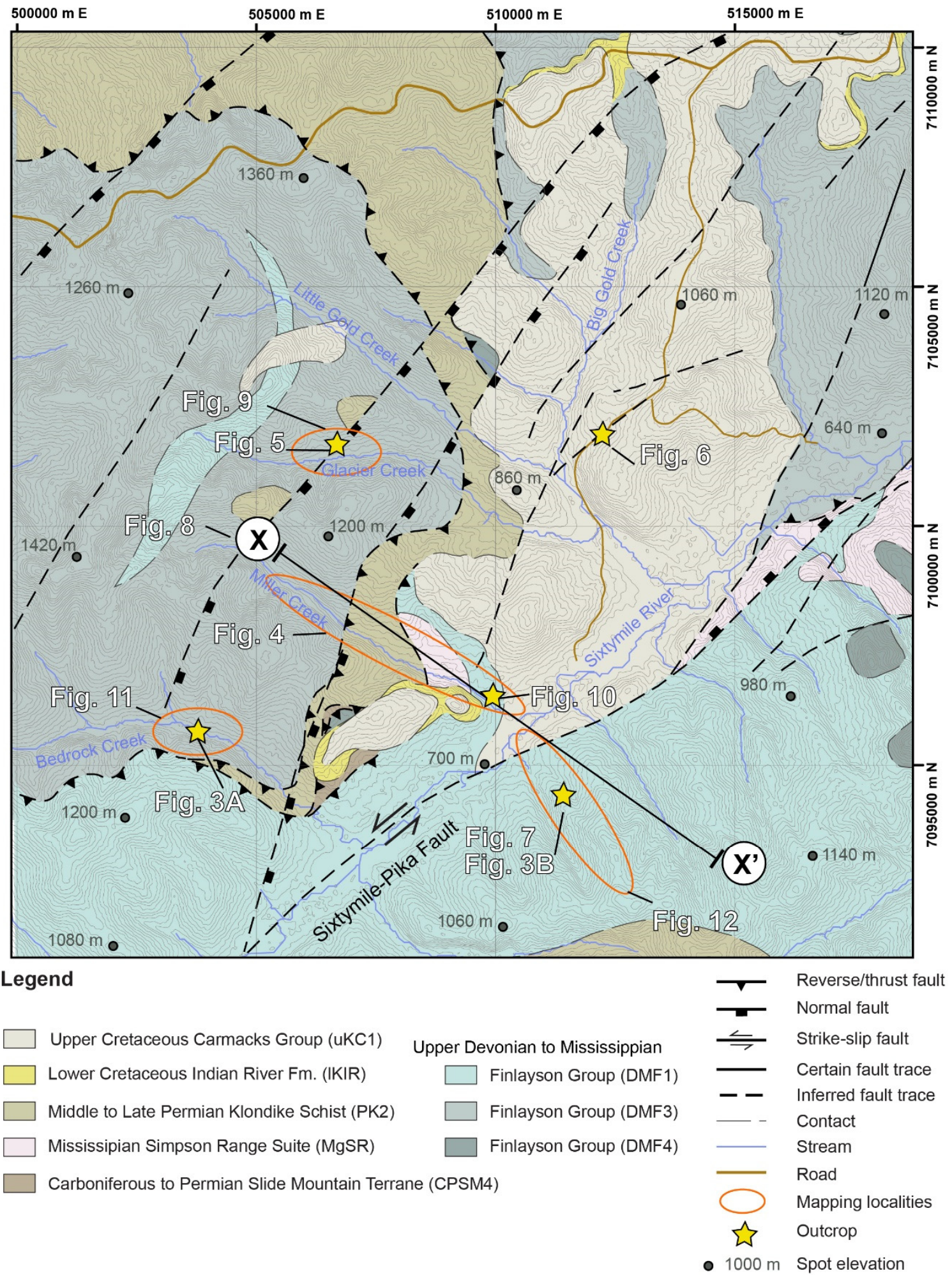

Figure 2. Local geology of the Sixtymile area which consists of a range of units which span the Mesozoic and Paleozoic (modified after maps by Mortensen, 1996, and the Yukon Geological Survey, 2020) $[18,23]$. Abbreviations of geological formations are from the Yukon Geological Survey (2020). Contour interval is $20 \mathrm{~m}$. 


\section{Geologic Background}

The Sixtymile mining district lies in the Tintina Gold Belt that spans more than $1000 \mathrm{~km}$ along the North American Cordillera (Figure 1). The Tintina Gold belt hosts diverse types of gold deposits (e.g., orogenic, intrusion-related epithermal, porphyry, skarns, etc.) that developed as a result of Late Jurassic to Late Cretaceous arc magmatism. The initiation of plutonism and fluid migration in the region supposedly correlates well with the onset of oblique subduction, and movement of the major right-lateral strike-slip Denali, Tintina, and associated fault systems $[8,24,25]$. The $~ 150$ km-long Sixtymile-Pika Fault (Figure 1), a Late Cretaceous, NE-SW-striking, sinistral strike-slip fault system, with possibly up to $\sim 30 \mathrm{~km}$ of displacement, is a major 'orogen-perpendicular' structure that runs through the Sixtymile mining district $[8,22,26,27]$. Previous regional analyses suggest this fault possibly exerted a structural control on Late Cretaceous localization of intrusions and volcanic deposits, as well as porphyry, skarn, and epithermal style deposits and occurrences in the region, which include high-grade gold (up to $\sim 20 \mathrm{~g} / \mathrm{t}$ ) $[21,28]$.

The geology of the Sixtymile district is characterized by a range of Mesozoic to Paleozoic units (Figure 2), that were originally documented in detail and given abbreviations, which we use throughout the text, by MacKenzie et al. (2008) [5]. The area is underlain by a basement composed of stacked thrust slices including the Upper Devonian to Mississippian Finlayson Group (DMF1, 3 and 4), Mississippian Simpson Range Suite (MgSR), Middle to Late Permian Klondike Schist (PK2), and Carboniferous to Permian Slide Mountain Terrane (CPSM4), which are overlain by the Lower Cretaceous Indian River Formation (IKIR) and the Upper Cretaceous Carmacks Group (uKC1) [5,23].

The Upper Devonian to Mississippian Finlayson Group exposed in the area is composed of intermediate to mafic volcanic and volcaniclastic rocks, and mafic metamorphic rocks (DMF1); carbonaceous metasedimentary rocks, which includes the Nasina Schist (DMF3); and fine-grained siliciclastic and metavolcaniclastic rocks (DMF4) (Yukon Geological Survey, 2020). The Mississippian Simpson Range Suite (MgSR) consists of foliated to strongly foliated, fine to medium-grained granodiorite to tonalite rocks [23]. The Middle to Late Permian Klondike Schist includes felsic, intermediate and, mafic metavolcanics intercalated with metaclastic rocks. While the Klondike Schist in the area was mapped by the Yukon Geological Survey (2020) [23] as mostly muscovite and/or chlorite quartz phyllite and quartzites (PK2), greenschist facies chloritic, quartzofeldspathic, and micaceous schists, similar to those described by Mortensen (1990) [29] in the Klondike field, can also be found in the area. The Carboniferous to Permian Slide Mountain Terrane (CPSM4) is composed mostly of serpentinized ultramafic rocks [23]. The Lower Cretaceous Indian River Formation (IKIR) is a sedimentary sequence dominated by clast-supported, pebble-to-cobble conglomerate with clasts composed of vein quartz, foliated quartzite, sandstone, and tuff [30]. The IKIR is unconformably overlain by the Upper Cretaceous Carmacks Group ( $\mathrm{uKC} 1$ ) is a volcanic succession of mostly mafic (e.g., basalt), and to a lesser extent intermediate (e.g., andesite), and locally felsic (e.g., trachyte) layers, usually with a base that exhibits a downward transition from coarse clastic sedimentary rocks (i.e., conglomerate) into an autochthonous basement breccia [31].

In the nearby Klondike district, Mackenzie et al. (2008) [5] proposed a structural evolution that consists of five deformation stages, which due to proximity, possibly also governs the structural setting of the Sixtymile mining district: an initial stage of compression in the Permian that resulted in foliation (D1); a second stage of compression, also in the Permian, causing pervasive foliation (D2), which involved parallel sub-parallel superimposition of remnants of D1 foliation to D2 foliation; a third stage of compression, which involved thrust stacking (D3) during the Jurassic (?); a fourth stage of compression, which involved faultfold deformation (D4) also during the Jurassic (?); and finally, a stage of regional extension in the Cretaceous, involving normal faulting (D5), through reactivation of D4 faults. 


\section{Methods}

\subsection{Geologic Mapping}

District-scale geological mapping was conducted by observing outcrops along roadcuts and stream exposures. Using a pocket transit and handheld global positioning systems (GPS) receivers, we took structural measurements and locations of faults, folds, foliation, veins, fractures, etc. Existing drillhole data (i.e., lithology, structures, gold assay) provided by Flow Metals Corp were also analyzed in 3D geologic modeling software. To verify the drilling logs, we inspected the diamond drill core samples at the Flow Metals Corp.'s Sixtymile district core storage facility and at the H.S. Bostock Core Library of the Yukon Geological Survey in Whitehorse City, Yukon. We also conducted a quality check of the structural measurements measured from digital-oriented core images, which were obtained through optical televiewer (OTV) surveys of the rotary airblast (RAB) drillholes in the property by Ground Truth Drilling Inc. (Dawson, YT, Canada). These data were used to evaluate dominant structural trends and trend correlations among different types of structures. These data were then utilized to construct a geological cross-section and cross-sections through key drillhole data.

\subsection{D Inversion of Potential-Field Geophysical Data}

Magnetic susceptibility is a dimensionless value that measures the degree of magnetization of material, such as rocks, when exposed to an external magnetic field [32]. Magnetic susceptibility is influenced by the type and concentration of magnetic minerals in rocks. In particular, the proportions of ferromagnetic (e.g., iron oxides or sulfides), paramagnetic (e.g., mafic silicates), and diamagnetic minerals (e.g., quartz or calcite) control the magnetic susceptibility of rocks [32,33]. While susceptibility values are not diagnostic of specific lithology, ferromagnetic minerals, which usually comprise the accessory minerals of rocks, exert a strong control on rock magnetic susceptibility and can be used as indicators of the processes/factors that influenced the formation of the geologic features associated with detected anomalies [32]. As such, analysis of magnetic data is a widely deployed tool in mineral exploration [34].

We employed a probabilistic method of 3D inversion of the existing magnetic dataset over the Sixtymile property to obtain subsurface 3D magnetic susceptibility models [35-40], which have been shown to be invaluable for constraining subsurface lithological distribution and structural geometries. The total magnetic intensity data were obtained through a low-level ( $<30 \mathrm{~m}$ sensor height) airborne survey with 100-200 $\mathrm{m}$ line spacing by Precision Geosurveys Inc. (Langley, BC, Canada) in 2010 [41].

The inversion method that we applied has the advantage of allowing the incorporation of a priori information, such as physical properties, spatial extent, depth and orientation of the source bodies, by variogram and equality constraint to produce an accurate and reliable solution [35-38].

The objective function for the inversion is composed of two parts: (1) a data misfit function - weighted by the data error covariances, and (2) a stabilizing function-the deviation of estimated model parameters from a reference model weighted by the model covariances $[37,38]$. The data error covariances were set equal to the noise level of the dataset, while the model covariance matrix was estimated with variogram functions based on geostatistics. The three orthogonal ranges, the easting, northing and depth directions (or the $\mathrm{x}, \mathrm{y}$, and $\mathrm{z}$ axes), represent a spatial correlation with the main geologic features. For the inversion of local targets (e.g., ore bodies), the ranges were set equal to the three spatial lengths of the main targets. As the ranges increased, the recovered models became smoother. Having a priori information regarding the physical properties enabled a reasonable distribution of the anomalous susceptibilities in different user-defined layers [37].

The inversion domain was divided into $50 \mathrm{~m} \times 50 \mathrm{~m} \times 10 \mathrm{~m}$ prism cells in the $\mathrm{x}, \mathrm{y}$, and $\mathrm{z}$ axes, respectively, and its depth range was set to $1000 \mathrm{~m}$. The inversion domain's dimensions were increased by $300 \mathrm{~m}$ beyond the coverage of the data in the $\mathrm{x}$ and $\mathrm{y}$ axes to prevent edge effects. This parameterization produces a prism model 
with 222, 159, and 100 cells in the $x, y$, and $z$ axes, respectively. The top surface of the inversion model was confined by the available 30 m-resolution Advanced Spaceborne Thermal Emission and Reflection Radiometer (ASTER) global digital elevation models (GDEM) (https://asterweb.jpl.nasa.gov/gdem.asp; accessed 13 June 2021). The three ranges were set as $300 \mathrm{~m}, 300 \mathrm{~m}$, and $100 \mathrm{~m}$ in the $\mathrm{x}, \mathrm{y}$, and $\mathrm{z}$ axes, respectively, to recover a relatively smooth susceptibility model. For this inversion, a depth-weighting function was applied [42]. We assigned a $0.5 \mathrm{nT}$ data error parameter, which is equivalent to the noise level of the magnetic data. Since a priori information on the basement in the study area was absent, we used a reference model with all the cells having values of 0 SI in the inversion.

The point cloud output of the inversion was uploaded to the Leapfrog software and the radial basis function ( $\mathrm{RBF}$ ) interpolation method was applied to produce a continuous smooth magnetic susceptibility model. We produced a series of cross-sections through this magnetic susceptibility model at an azimuth of $305^{\circ}$ to be parallel to the geologic cross-section also produced independent in this study based on geological data, which displays the main structural fabric of the area.

To provide actual magnetic susceptibility values that we could correlate with geophysical inversion-derived values, we took measurements using a multi-parameter probe MPP-EM1 magnetic susceptibility and conductivity meter by Instrumentation GDD on the available diamond drill core samples at the Flow Metals Corp's Sixtymile district core storage facility and at the H.S. Bostock Core Library of the Yukon Geological Survey in Whitehorse City, Yukon. Measurements were taken on samples of different lithologies and at different depths for samples from the same drillhole. The magnetic susceptibility values were recorded in $10^{-3}$ SI. While the device also measures elative (HF response) and absolute EM conductivity (MHOS/M) values, all the samples we measured yielded values below the detection limit $\left(1 \times 10^{-3} \mathrm{SI}\right)$.

We inspected hand specimen and thin sections of select core samples (Supplementary Figures S1-S36) using a polarizing microscope to provide a lithological context for the measured and modeled magnetic susceptibility values. Lastly, we correlated the 3D magnetic susceptibility models to all the available topographic, geological, and geochemical datasets on the 3D geological modeling software, Leapfrog.

\section{Results}

The following subsections describe our measurements of mesoscopic-scale structures, the results of our 3D probabilistic inversion of total magnetic intensity data for magnetic susceptibility, and analysis of some assay data derived from drillhole samples.

\subsection{Structural Measurements and Observations}

Foliation, ranging from slaty cleavage to schistosity (Figure 3A,B), is defined by the alignment of micas (Figure 3C,D; muscovite, and less commonly biotite), and is associated with foliation-parallel lens-shaped and/or boudinage quartz veins that occasionally display sulfide mineralization (Figure 4). Foliation was mainly observed in the Nasina Schists of DMF3, and the light-colored schists of DMF1. Fractures affect all units (Figure 5) and exhibit dominant trends in certain localities. Veins are associated with foliation, but are also found along fractures and fault planes (Figures 5 and 6). Outcrops with faults were limited in the Sixtymile mining district, with only two unequivocal faults identified in this study: (1) A NE-SW-striking, steeply SE-dipping oblique reverse fault along the Sixtymile road (Figure 6, Table 1; star labeled 'Figure 6' in Figure 2); and (2) a nearly N-S striking, steeply dipping strike-slip fault in the Sixtymile River area (Figure 7, Table 1; star labeled 'Figure 7' in Figure 2). 

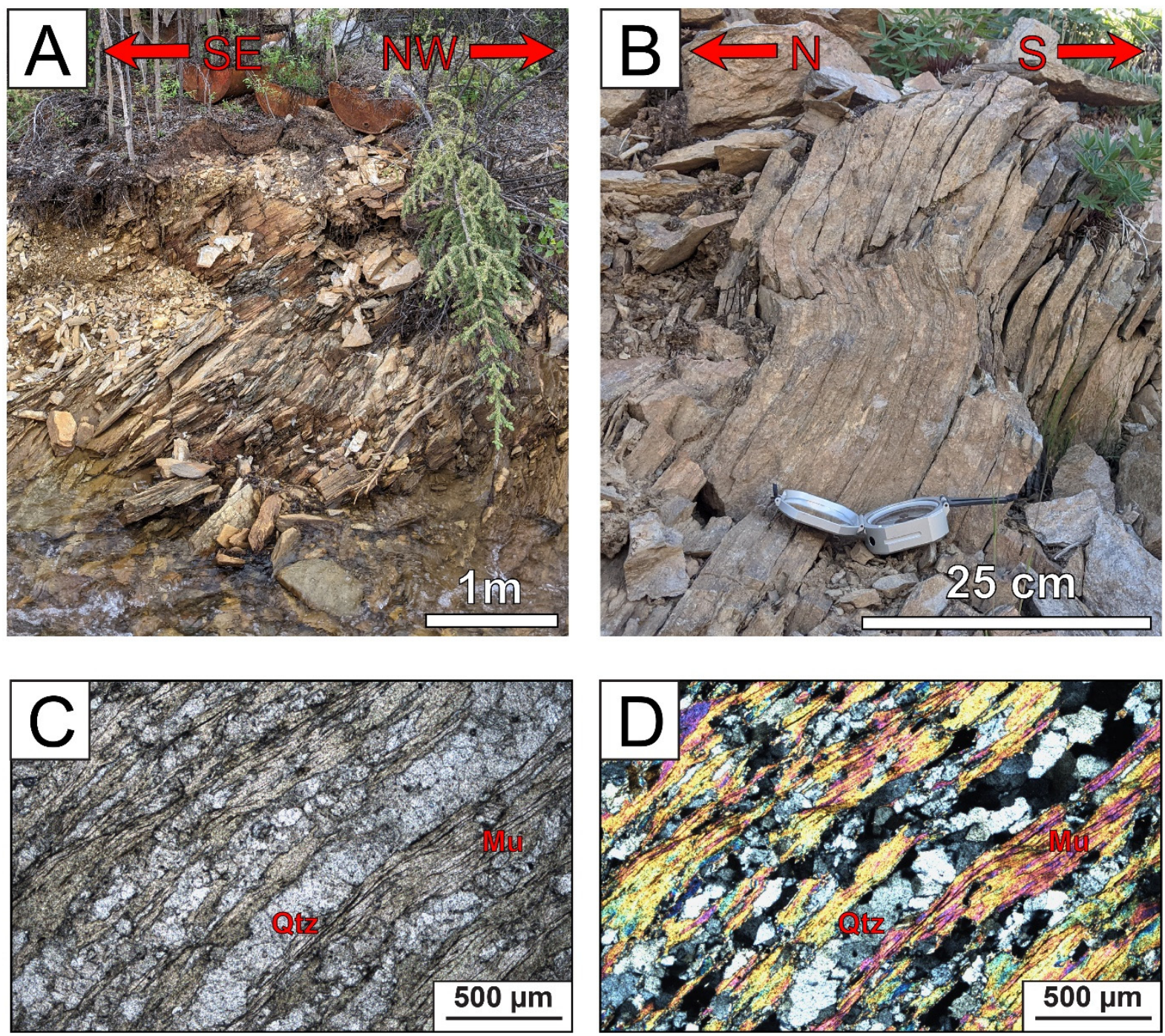

Figure 3. Examples of foliation in the study area. (A) Moderately SE-dipping foliation of Nasina Schists, which belong to the Upper Devonian to Mississippian Finlayson Group (DMF3) along the Bedrock Creek. (B) Steeply NE-dipping foliation of lighter-colored schists that belong to the Upper Devonian to Mississippian Finlayson Group (DMF1) in the Sixtymile River area. Refer to Figure 2 for location. (C) Plane polarized light thin section view of a sample from the Middle to Late Permian Klondike Schist (PK2), a strongly foliated, fine- to coarse-grained muscovite quartz schist (Sample DDH-11-15-3, 224.90 m-233.33 m; see Supplementary Figures S1, S3 and S12E for sample location maps and a hand specimen image). Alternating layers of mica and quartz crystals with an evident preferred orientation can be observed. (D) Cross-polarized light view. Qtz-quartz, Mu—muscovite.

Table 1. Fault structural measurements.

\begin{tabular}{ccccc}
\hline Reading & Strike & Dip & Lineation Azimuth & Plunge \\
\hline R1 & 59 & 76 & 225 & 25 \\
R2 & 66 & 72 & 229 & 40 \\
R3 & 59 & 59 & - & - \\
SS1 & 196 & 78 & 10 & 6 \\
SS2 & 169 & 80 & 356 & 1 \\
SS3 & 185 & 70 & 342 & 32 \\
\hline
\end{tabular}



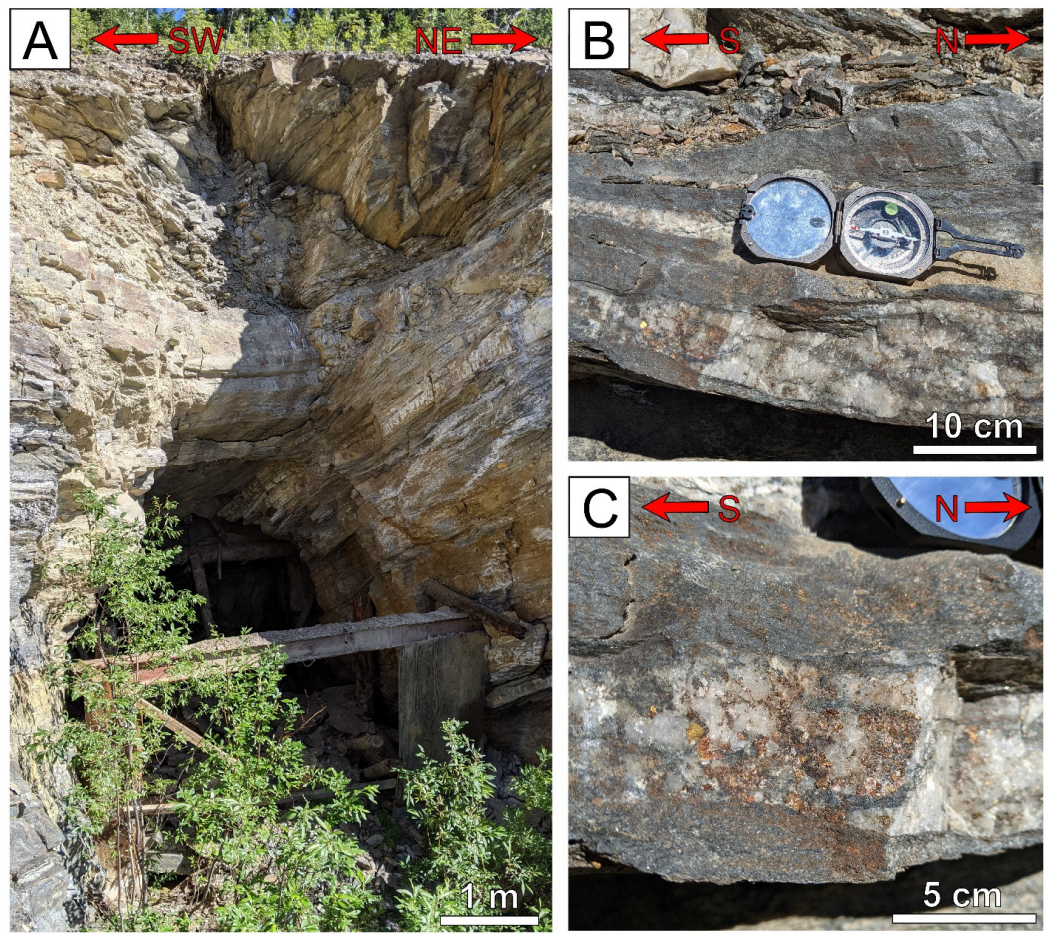

Figure 4. Foliation-parallel veins and boudins in the NW-SE-striking, NW-dipping Nasina Schists, which belong to the Upper Devonian to Mississippian Finlayson Group (DMF3). (A) Abandoned adit which cuts through the Nasina schists in the Miller Creek area. (B,C) Disseminated sulfide mineralization can be observed in lens-shaped and boudinage quartz veins. Refer to Figure 2 for location.
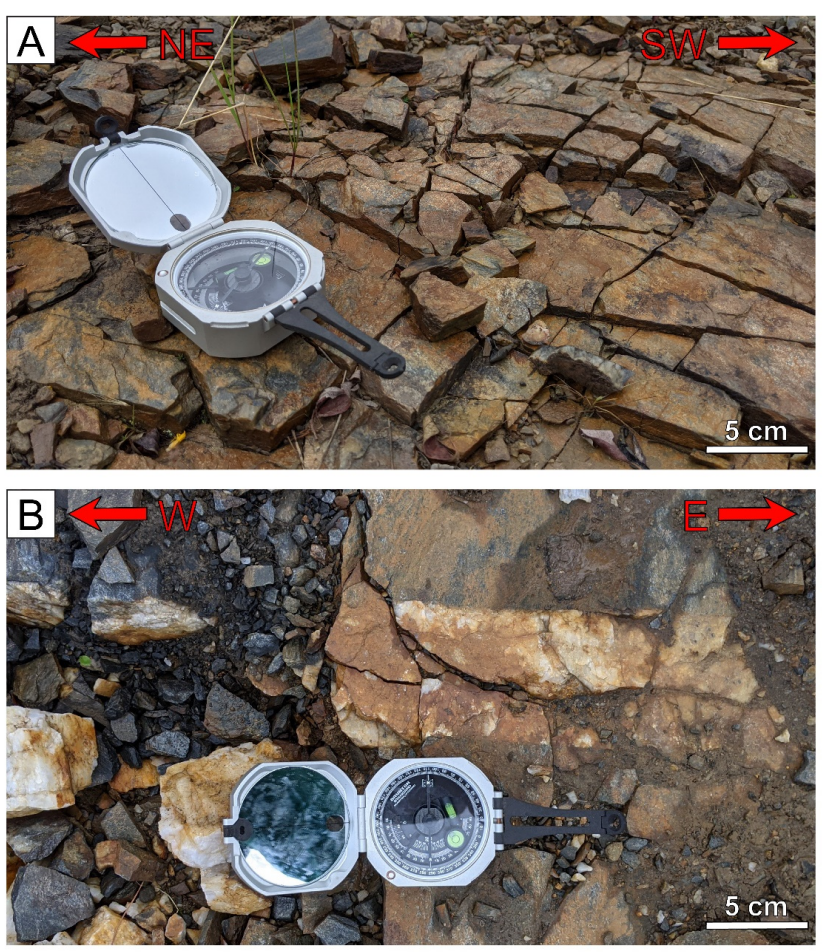

Figure 5. Near-vertical fractures and veins in the Glacier Creek area cutting Nasina Schists, which belong to the Upper Devonian to Mississippian Finlayson Group (DMF3) (A,B). Refer to Figure 2 for location. 

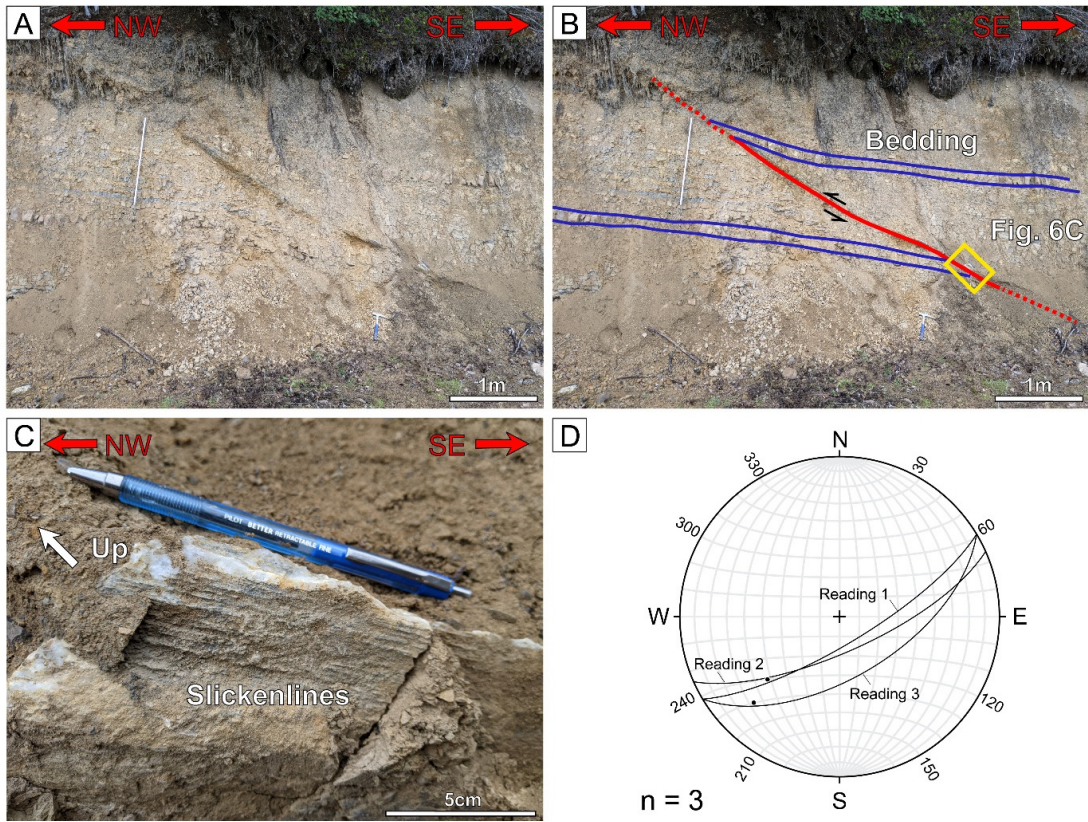

Figure 6. A NE-SW-striking, SE-dipping oblique (sinistral) reverse fault with $>1 \mathrm{~m}$ apparent vertical offset cutting through the Upper Cretaceous Carmacks Group (uKC1), along the Sixtymile road. (A) Uninterpreted outcrop photo. (B) Interpreted outcrop photo. (C) A blown-up image of the slickensided fault plane. The location of this image is indicated by the yellow box in (B). Refer to Figure 2 for location. (D) Stereographic projections of fault planes and lineations of the oblique reverse fault along the Sixtymile Road. Structural readings for this oblique reverse fault are listed in Table 1 as "R1, R2".
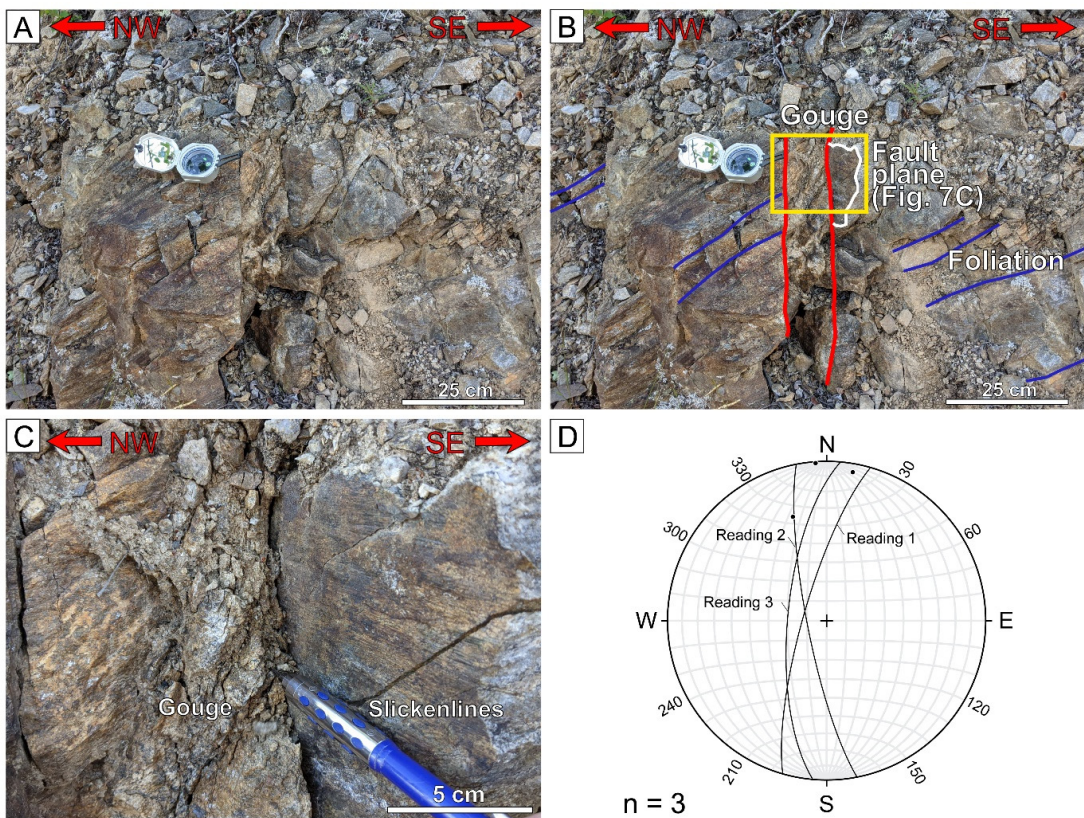

D

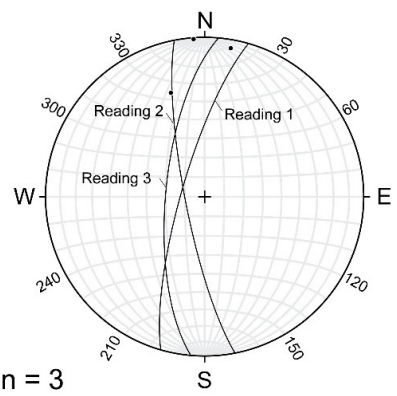

Figure 7. Close-up view of the gouge and slickenlines on the nearly N-S-striking strike-slip fault south of the Sixtymile river shown in Figure 8. (A) Uninterpreted outcrop photo. (B) Interpreted outcrop photo. (C) A blown-up image showing the slickensided fault plane and fault gouge. The location of this image is indicated by the yellow box in (B). Refer to Figure 2 for location. (D) Stereographic projections of fault planes and lineations of the strike-slip fault in the Sixtymile River area. Structural readings for this strike-slip fault are listed in Table 1 as "SS1, SS2". 


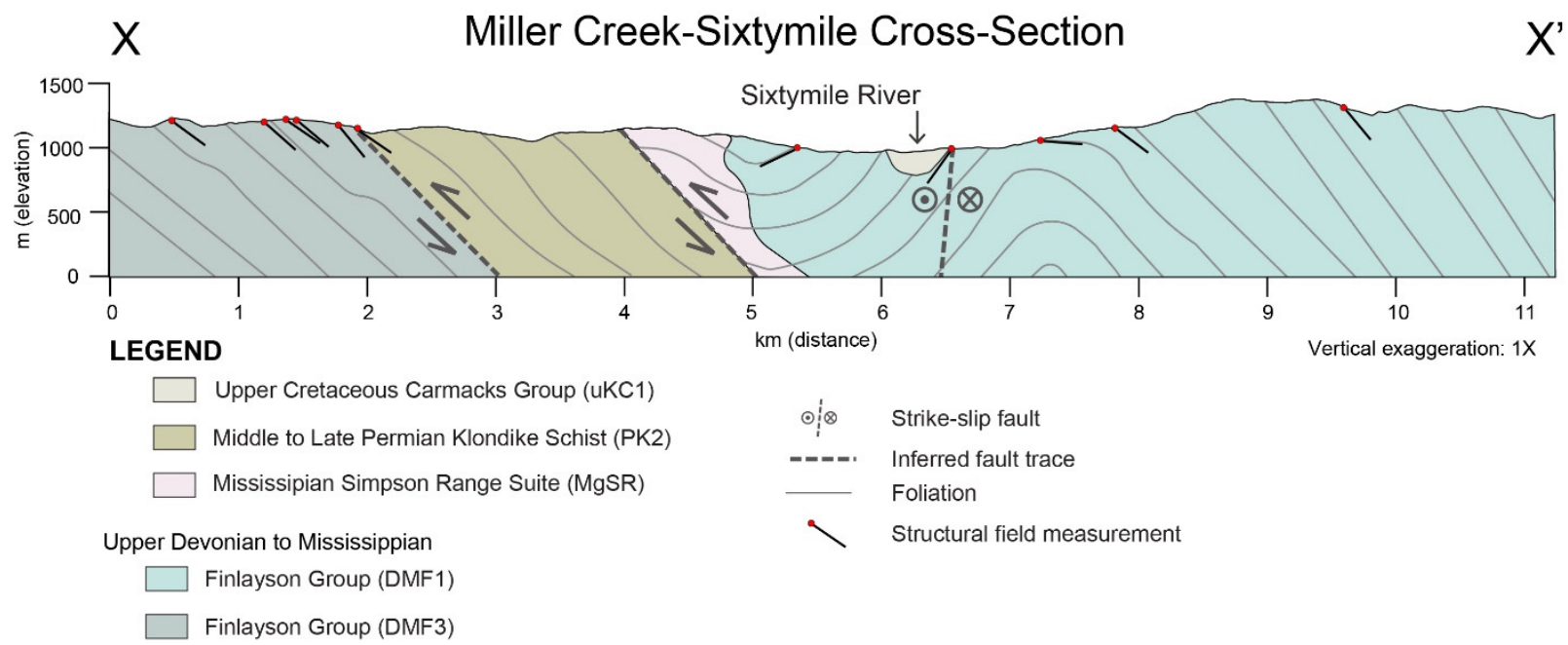

Figure 8. Geologic cross-section along Miller Creek and across the Sixtymile River. See Figure 2 for the location of this cross-section.

The NE-SW-striking, steeply SE-dipping oblique reverse fault along the Sixtymile road exhibits $>1 \mathrm{~m}$ vertical offset across the Upper Cretaceous Carmacks Group (uKC1) (Figure 6, Table 1; star labeled 'Figure 6' in Figure 2). The road cut exposure of the fault makes the fault dip appear lower than it actually is; three readings (Table 1) taken on the fault plane indicate a steep dip angle ranging from $\sim 60-80$ degrees. A $2-3 \mathrm{~cm}$ vein follows the fault plane. The nearly N-S striking, steeply dipping strike-slip fault was observed to be cutting through schists belonging to DMF3 (Figure 7, Table 1; star labeled 'Figure 7' in Figure 2).

\subsubsection{Geologic Cross-Section}

We illustrate the major structural features and the stratigraphic relations of most of the units in a geologic cross-section which runs NW-SE along Miller creek (Figure 8). The cross-section through the Miller Creek in the Sixtymile mining district shows E-dipping basement rocks (Figure 8), including DMF3 and PK2, that are stacked against each other along a top-to-the-NW reverse fault contact (Figure 8). This fault was first documented by Mortensen (1996) [43] and is reflected in the maps of the Yukon Geological Survey (2020) [23]. This reverse fault is shown on the geologic map (Figure 2) as being reactivated along some segments by normal faulting resulting from localized extension related to the left-stepover of the left-lateral Sixtymile-Pika Fault in the area. Further east, the extensively folded Upper Devonian to Mississippian Finlayson Group intermediate to mafic volcanic and volcaniclastic rocks, and fine-grained amphibolite and greenstone (DMF1) is in thrust contact with the PK2 (Figure 8). This unit is also in contact with the metamorphosed intrusive MgSR, and is also unconformably overlain by the volcanic succession of mostly mafic, and to a lesser extent, intermediate rocks of $\mathrm{uKC} 1$. The intrusion of the MgSR precedes the top-to-the-NW thrusting of the DMF1 against PK2 (Figure 8). A 'Thrust Zone,' described mainly from horizontal loop electromagnetic (HLEM) and induced polarization (IP)-resistivity data has been recognized by Hulstein (2011) [44], albeit with an opposite SE vergence.

\subsubsection{Localities}

We displayed structural measurements taken from outcrops (Figures 3-5) and drillhole logs (diamond drill cores and optical televiewer; Supplementary Figures S1-S9) as planar and polar stereonet plots separately for each of the following locations: Glacier Creek, Miller Creek, Bedrock Creek, and Sixtymile River (Figures 9-12). Orientations of structures are discussed per locality, since this allows observation of spatial variations in orientations. 

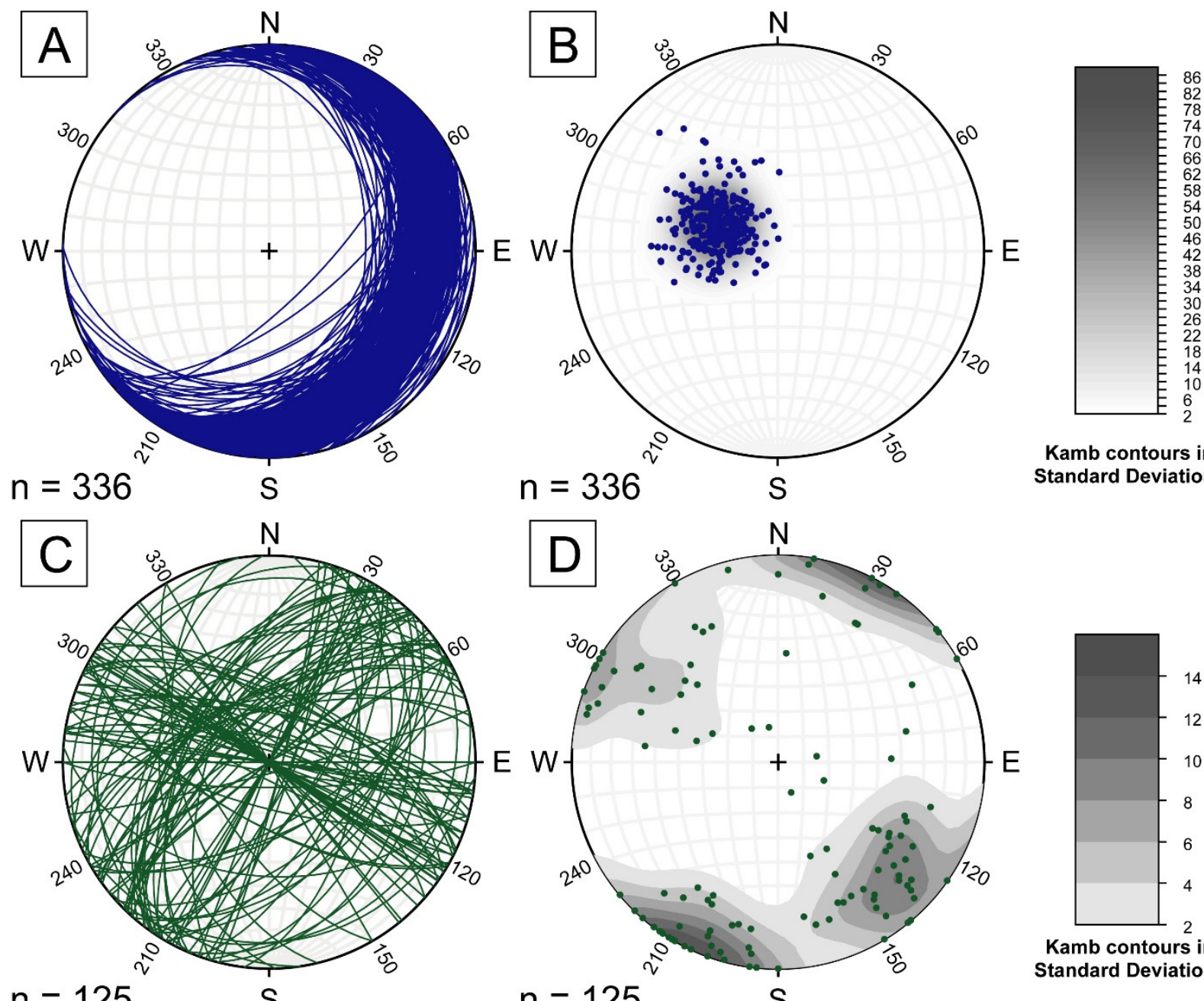

$n=336$

Kamb contours in

Standard Deviations
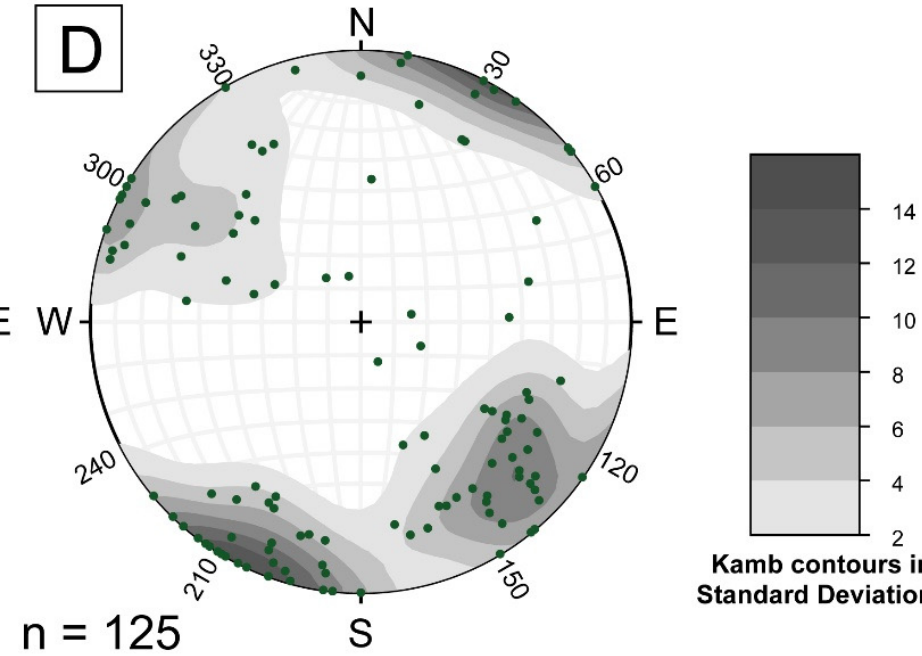

Kamb contours in

$\mathrm{n}=125$

$S$
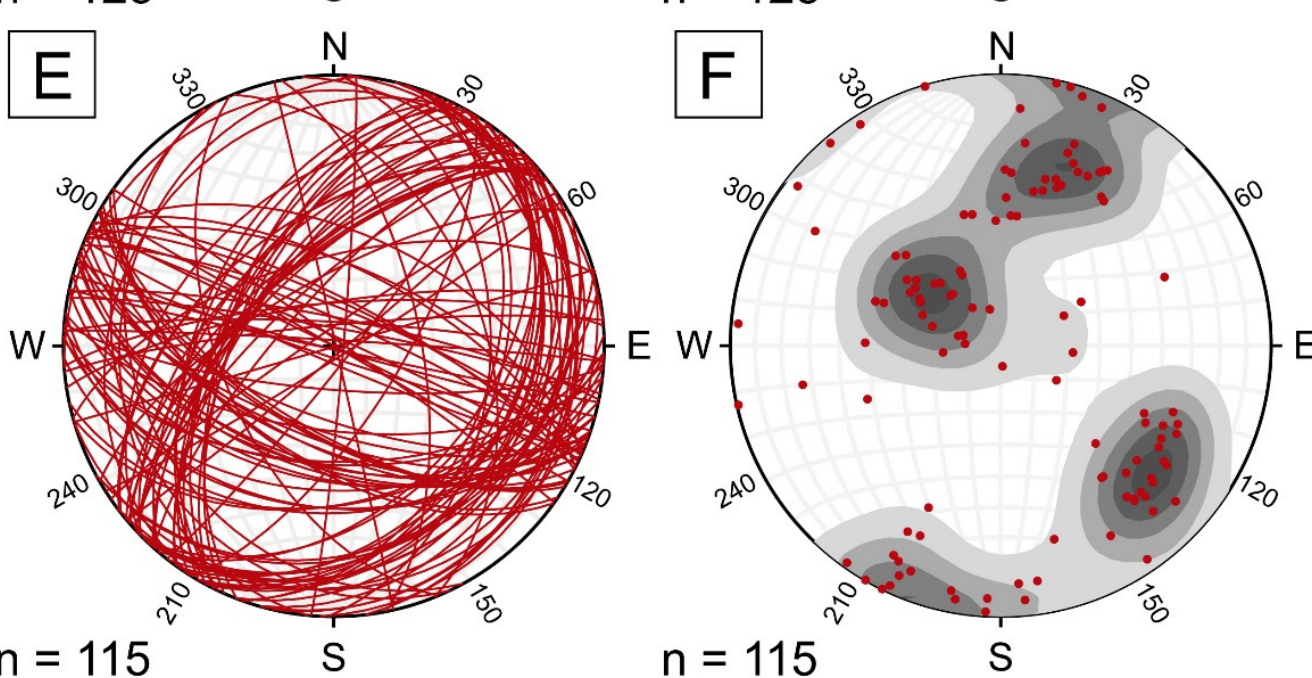

Standard Deviations

$\mathrm{n}=115$

$\mathrm{S}$

Fractures

Veins

Figure 9. Planar and polar (pole-to-plane) plots with density contours of structures in the Glacier Creek area (field and drillhole data). (A,B) foliation; $(\mathbf{C}, \mathbf{D})$ fractures; $(\mathbf{E}, \mathbf{F})$ veins. 

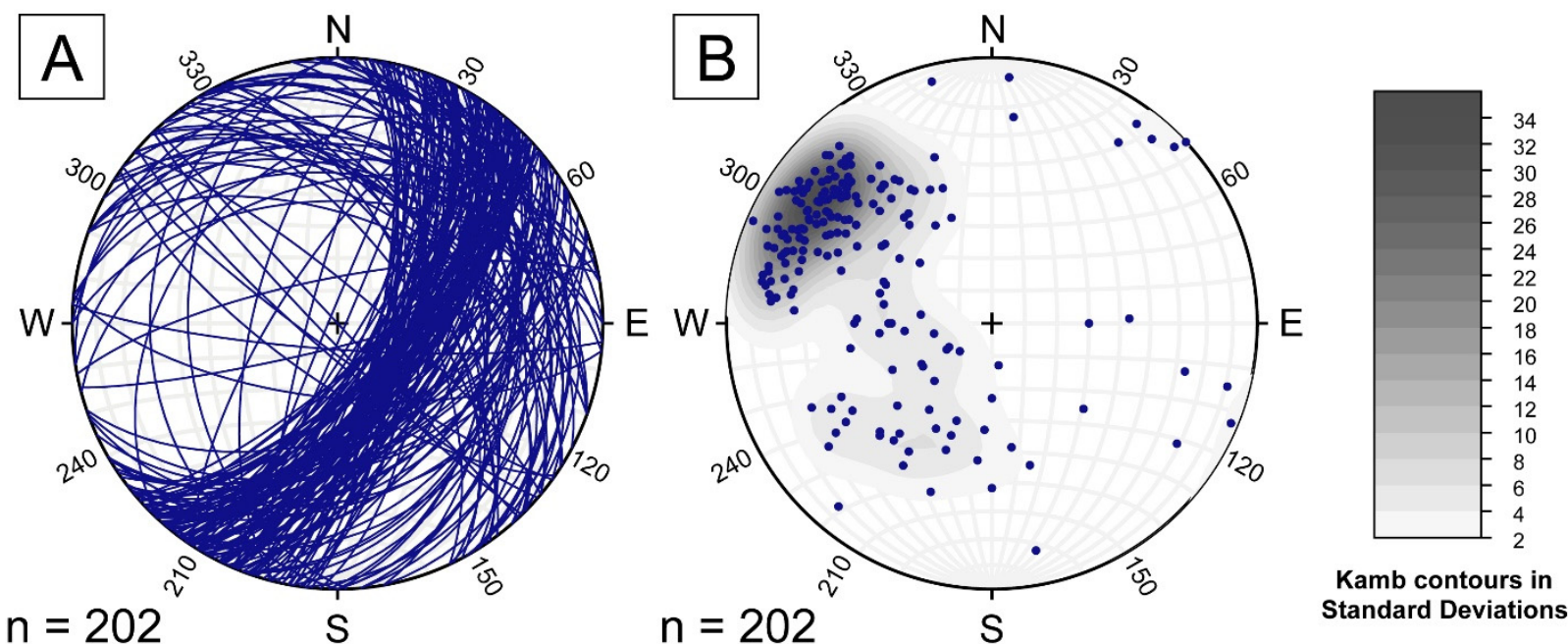

Kamb contours in
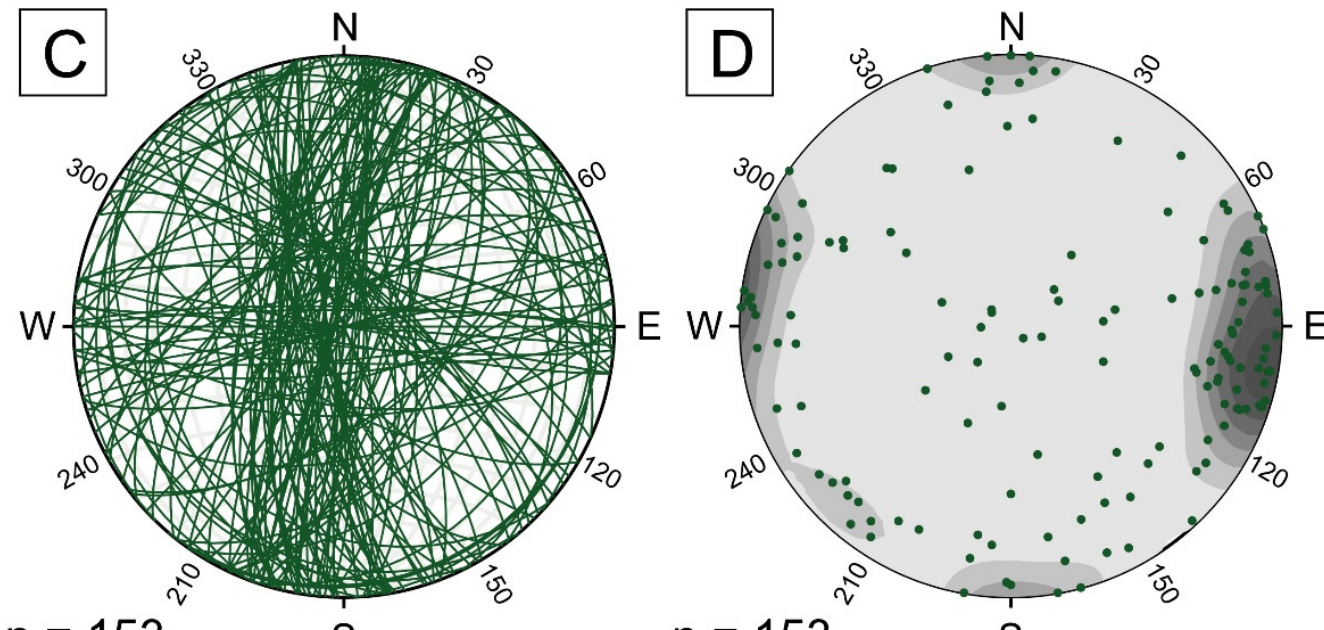

$\mathrm{n}=153$

$S$

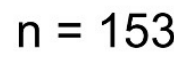

$\mathrm{S}$
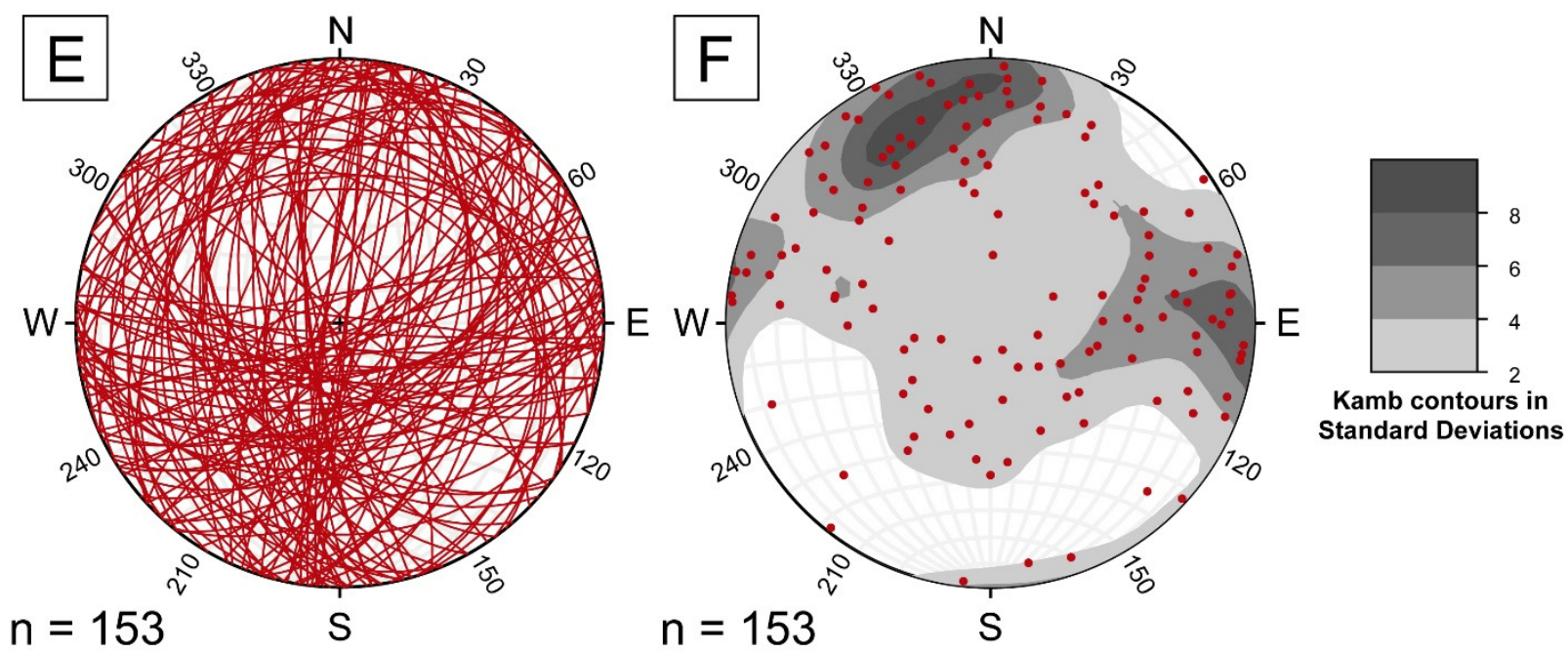

$n=153$

$\mathrm{S}$

Fractures

Veins

Figure 10. Planar and polar (pole-to-plane) plots with density contours of structures in the Miller Creek area (field and drillhole data). (A,B) foliation; $(\mathbf{C}, \mathbf{D})$ fractures; $(\mathbf{E}, \mathbf{F})$ veins. 

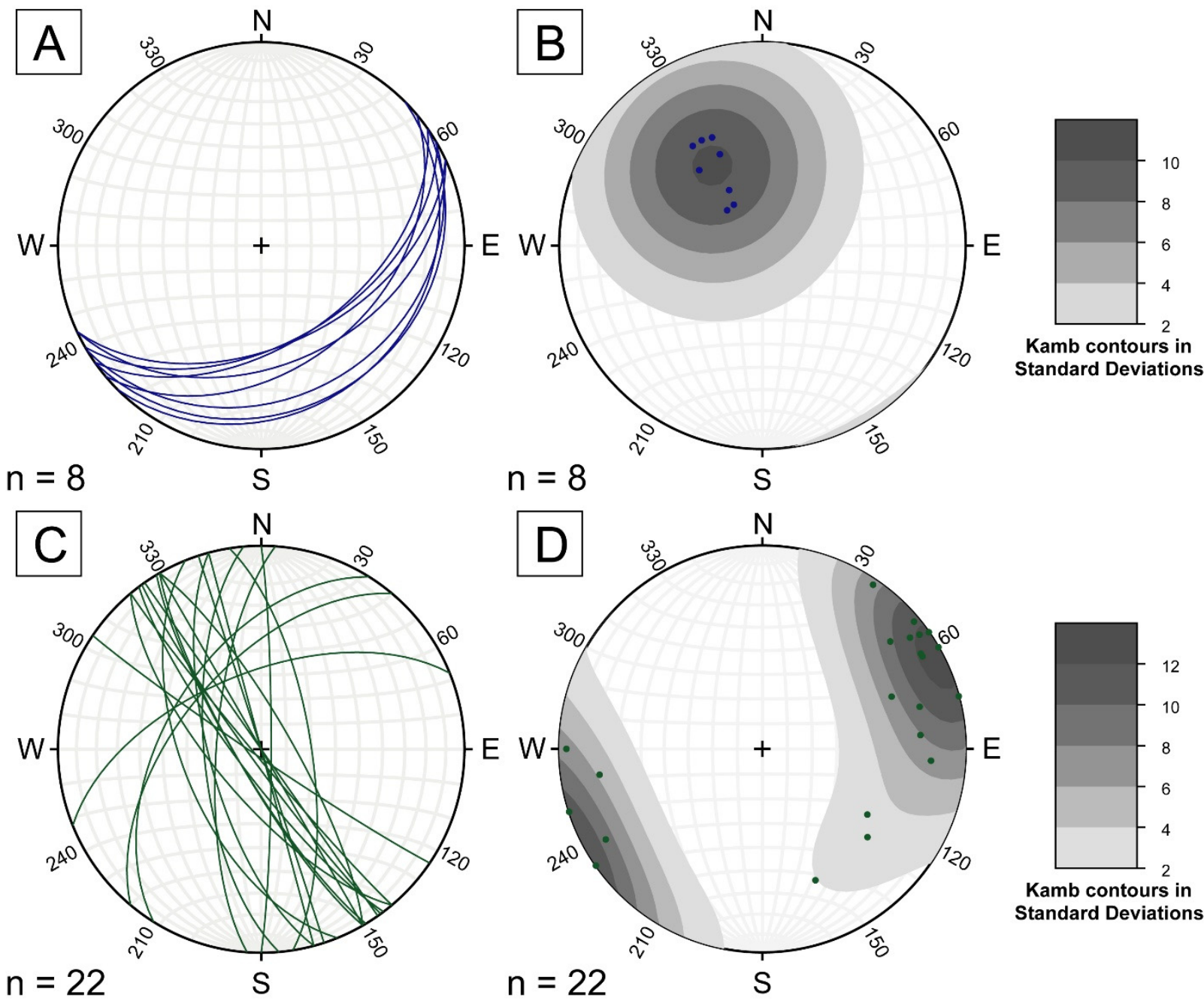

$\mathrm{n}=22$

$\mathrm{S}$

$\mathrm{n}=22$

Standard Deviations
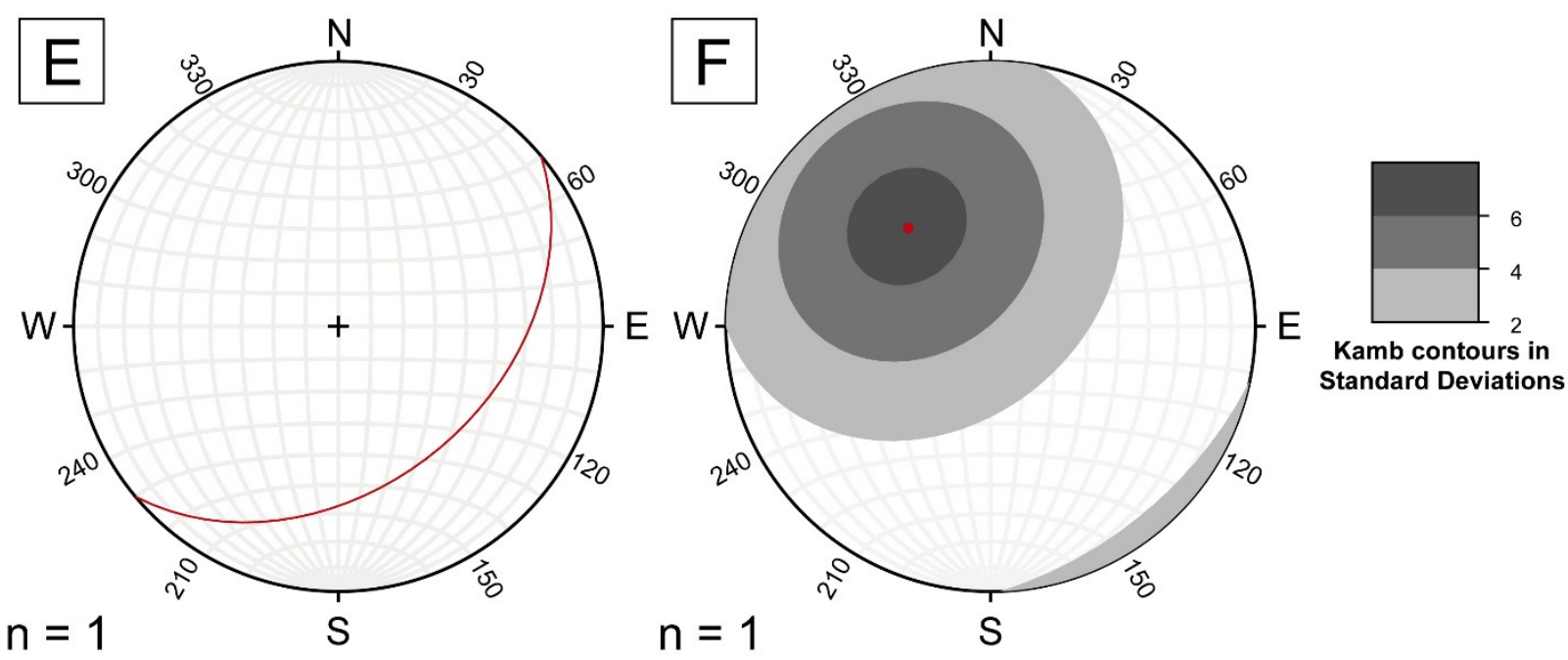

Foliation

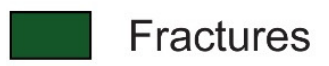

Veins

Figure 11. Planar and polar (pole-to-plane) plots with density contours of structures in the Bedrock Creek area (field and drillhole data). (A,B) foliation; (C,D) fractures; (E,F) veins. 

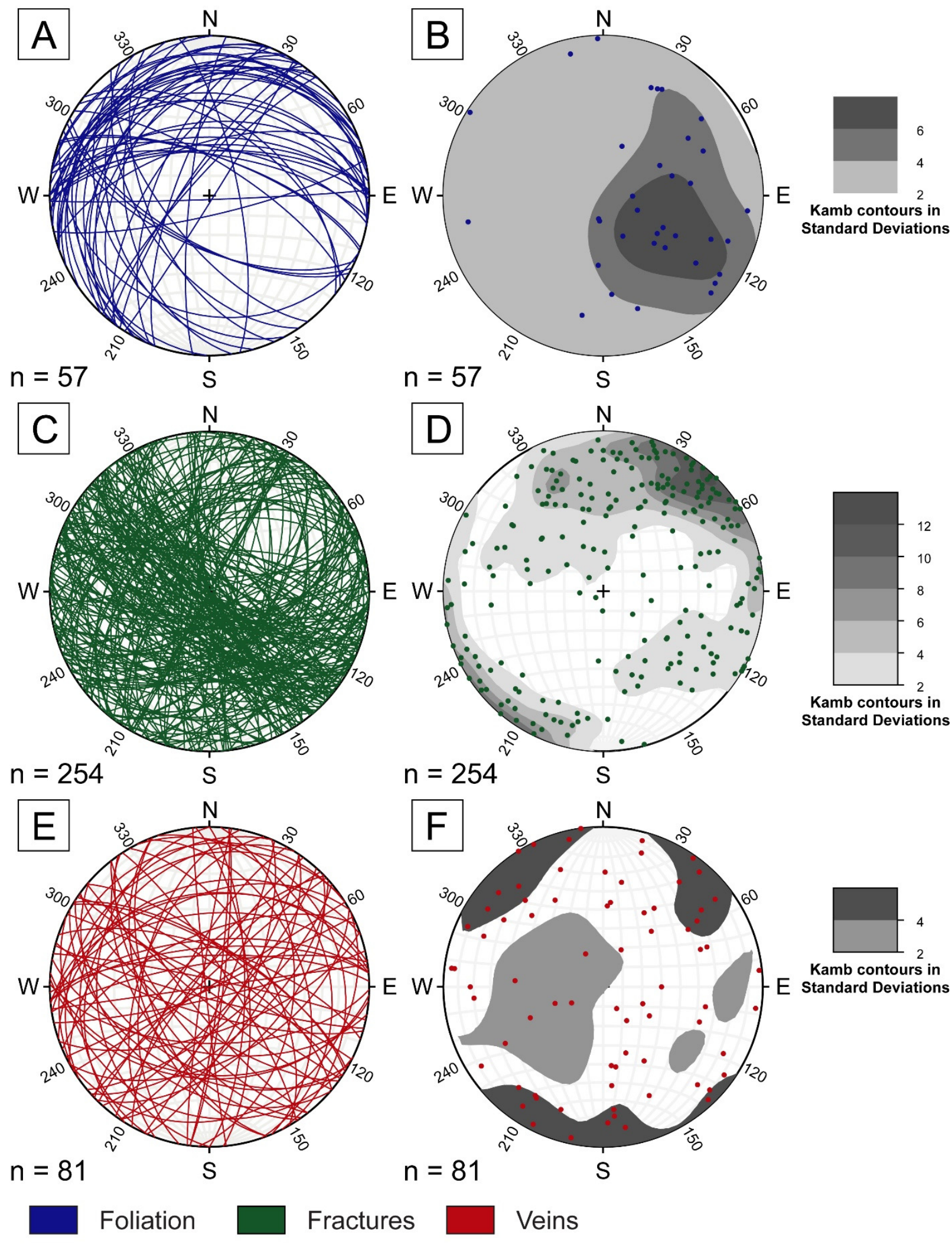

Figure 12. Planar and polar (pole-to-plane) plots with density contours of structures in the Sixtymile River area (field and drillhole data). (A,B) foliation; (C,D) fractures; (E,F) veins. 


\section{Glacier Creek}

Foliation planes in the Glacier Creek area (Figure 9A,B) are dominantly N-striking and E-dipping, and to a lesser extent NE-SW-striking and SE-dipping. On the other hand, fractures and veins are dominantly NE-SW and WNW-ESE-striking, with variable dip directions (Figure 9C-F). Foliation planes that are NE-SW-striking, gently SEdipping (Figure 9A,B); including fractures that are NE-SW-striking, steeply NW-dipping (Figure 9C,D), and NW-SE-striking, steeply NE-dipping (Figure 9C,D), are strongly correlated with the orientation of veins (Figure 9E,F).

\section{Miller Creek}

The majority of foliation planes in the Miller Creek area are NE-SW-striking, steeply SE-dipping, and to a lesser extent, NW-SE-striking, gently NE-dipping (Figure 10A,B). Fractures exhibit a wider range of orientations (Figure 10C,D), but still show clusters that are preferentially nearly N-S-striking, and either steeply $\mathrm{W}$ - or E-dipping. Veins in the Miller Creek area have a more random distribution of orientations compared to foliation and fractures (Figure 10E,F).

\section{Bedrock Creek}

The majority of foliation planes in the Bedrock Creek area are NE-SW-striking, gently SE-dipping (Figure 11A,B). Fractures are dominantly NW-SE striking and are either steeply NE- or SW-dipping. (Figure 11C,D). Veins, which are similarly NE-dipping, gently SEdipping (Figure 11E,F) tend to occur along or parallel to foliation planes.

\section{Sixtymile River}

Foliation planes in the Sixtymile River area (Figure 12A,B) are dominantly NW-SE- to NE-SW-striking and NE- to NW-dipping. NW-SE striking, SW-dipping foliation planes are less common and comprise very localized, minor folding. Fractures and veins exhibit a random distribution of orientations (Figure 12C-F).

\subsection{Magnetic Susceptibility}

The absolute magnetic susceptibility values recovered from the 3D inversion of aeromagnetic data in the Sixtymile property range from 0.0 to $270.0 \times 10^{-3} \mathrm{SI}$ (Figures 13 and 14). The relatively higher magnetic susceptibility values $\left(>18 \times 10^{-3} \mathrm{SI}\right)$ can be spatially correlated mostly with the dominantly extrusive igneous rocks of $\mathrm{uKC} 1$, and to a lesser extent, the intermediate to mafic volcanic and volcaniclastic rocks of the DMF1, which are distributed mainly to the east-southeast and southwest portions of the recovered model, respectively (Figures 13 and 14). Lower magnetic susceptibility values correspond to the carbonaceous metasedimentary rocks of DMF3, which are located mostly to the northwest of the recovered model (Figures 13 and 14). However, while we describe which geologic formations these magnetic susceptibilities coincide with at the surface, it should be noted that these formations may extend further towards a certain direction along the cross-sections in the subsurface, depending on their subsurface geometries and/or dip. The magnetic susceptibility values that we measured in the field to constrain our 3D inversion modeling ranged from 0.0 to $4.2 \times 10^{-3}$ SI (Supplementary Table S1). 

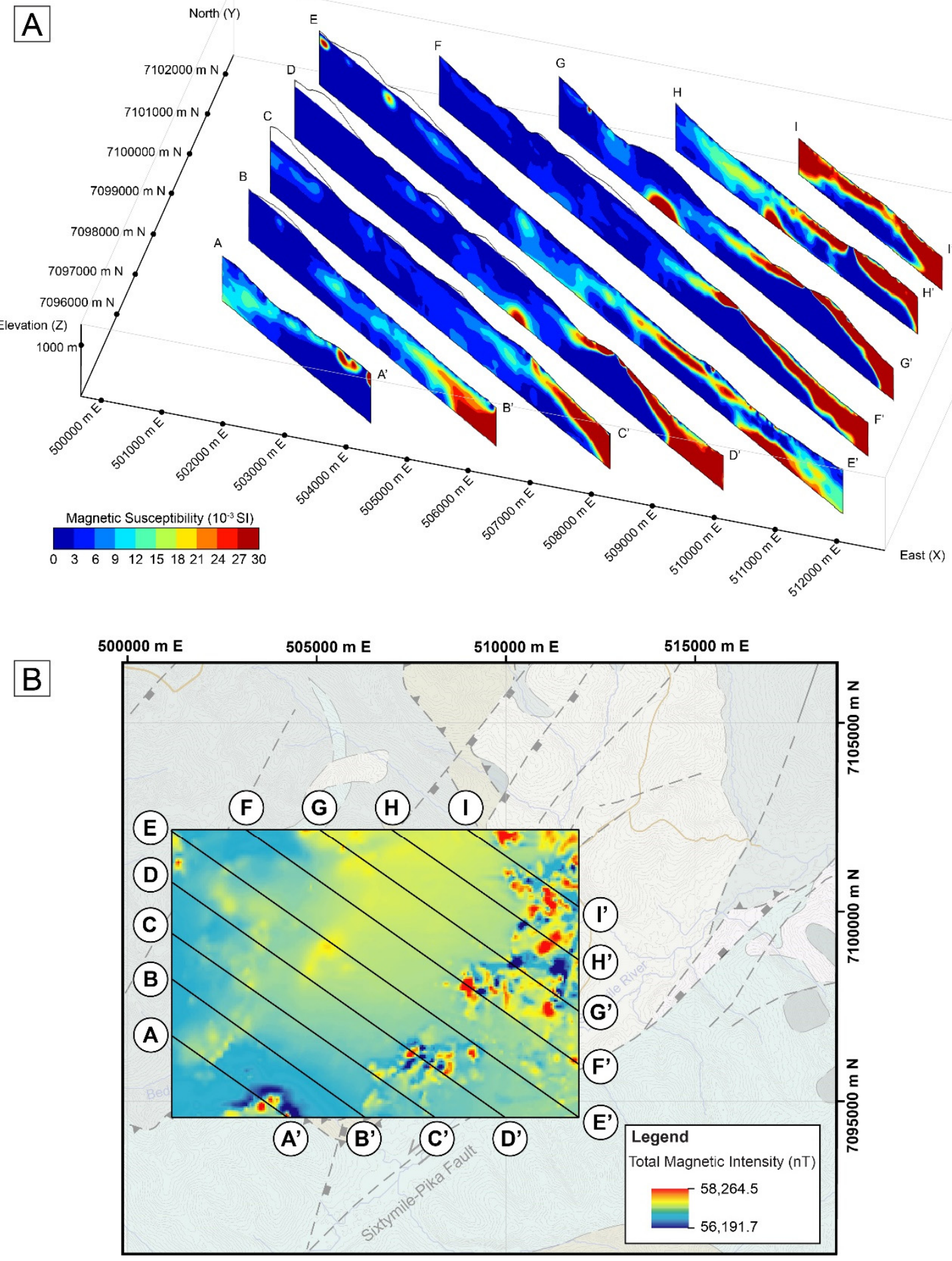

Figure 13. 3D magnetic susceptibility data. (A) Fence diagram of cross-sections through the 3D magnetic susceptibility data. (B) Map showing the locations of the cross-sections in (A) that are overlaid on the total magnetic intensity map on which the 3D inversion was conducted. 


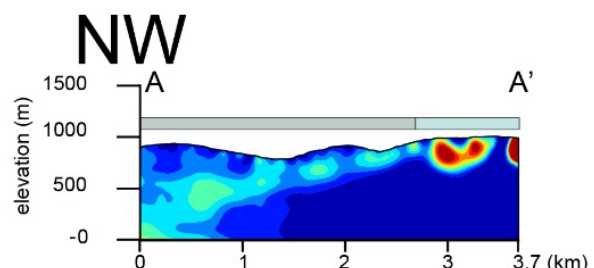

\section{SE}
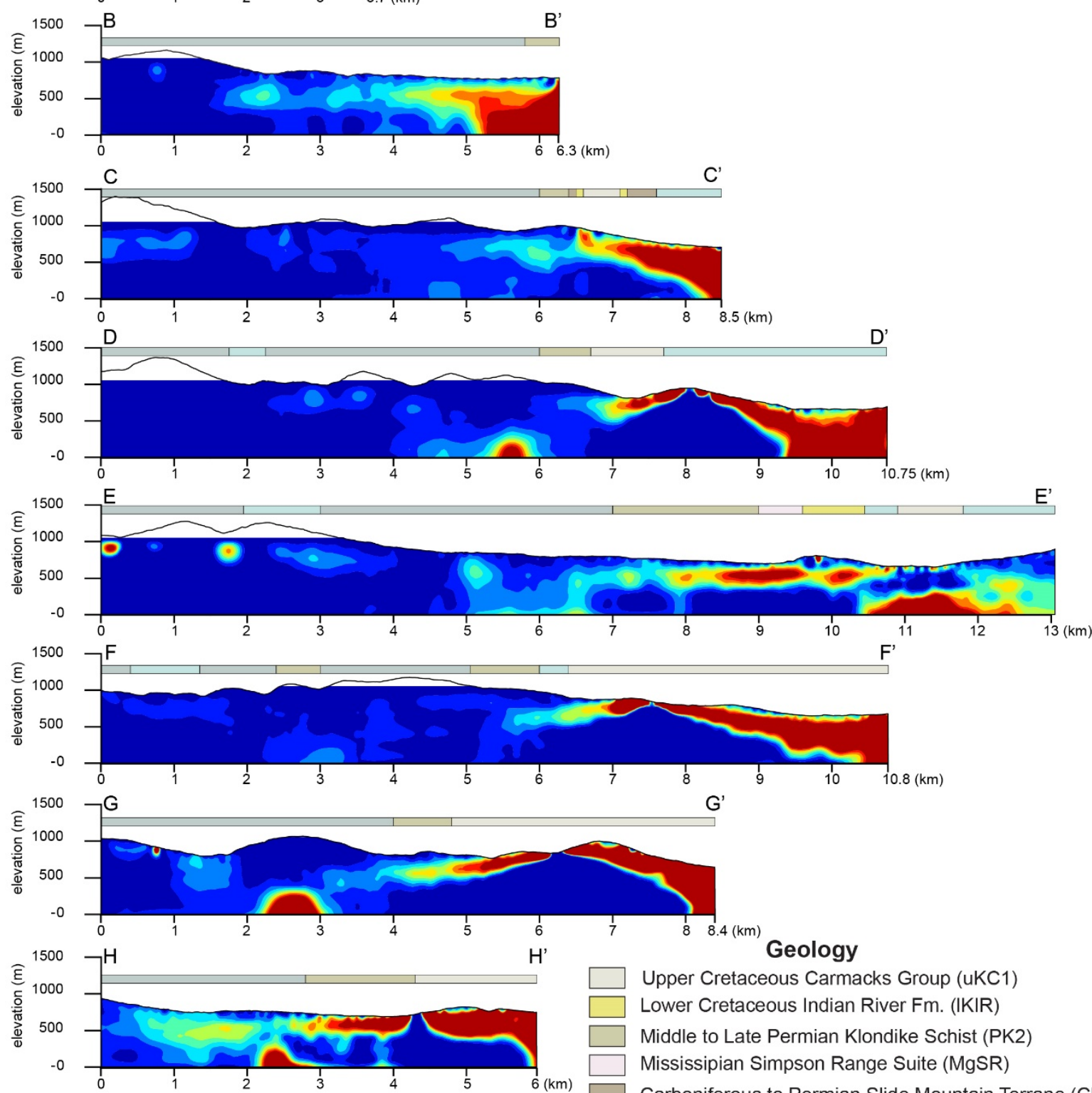

\section{Geology}

Upper Cretaceous Carmacks Group (UKC1)

Lower Cretaceous Indian River Fm. (IKIR)

Middle to Late Permian Klondike Schist (PK2)

Mississipian Simpson Range Suite (MgSR)

Carboniferous to Permian Slide Mountain Terrane (CPSM4)

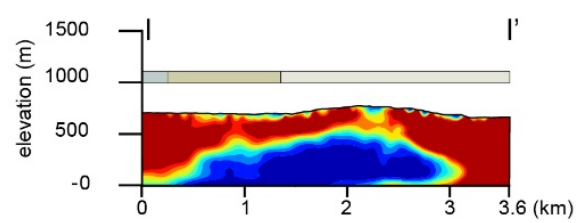

Upper Devonian to Mississippian Finlayson Group (DMF1)

Upper Devonian to Mississippian Finlayson Group (DMF3)

Magnetic Susceptibility $\left(10^{-3} \mathrm{SI}\right)$

$\begin{array}{lllllllllll}0 & 3 & 6 & 9 & 12 & 15 & 18 & 21 & 24 & 27 & 30\end{array}$

Figure 14. Cross-sections through the $3 \mathrm{D}$ magnetic susceptibility data juxtaposed to plots of the corresponding geologic units at surface.

The following are descriptions of the shapes, sizes, and locations of magnetic susceptibility anomalies (the location of each anomaly is stated as its distance from the northwest end of each cross-section): 
In section $\mathrm{A}-\mathrm{A}^{\prime}$ (Figures 13 and 14), magnetic susceptibility highs can be observed towards the southeast end between 2.75 and $3.70 \mathrm{~km}$ distance, and directly below the surface down to a depth of $\sim 250 \mathrm{~m}$. The first one includes two $200-300 \mathrm{~m}$-wide, nearly fused ovoid-shaped anomalies centered at around $3.25 \mathrm{~km}$. The second one, at the rightmost edge of the section, is a vertical, 300 m-long spheroidal-shaped anomaly. Both of these anomalies coincide with DMF1.

In section B-B' (Figures 13 and 14), an 700 m-high $\times \sim 1000$ m-wide, unevenly distributed roughly cuboid magnetic susceptibility high is similarly found closer to the southeast end, at $250 \mathrm{~m}$ below the surface and between 5.30 and $6.30 \mathrm{~km}$ distance. The distribution of higher magnetic susceptibility values resembles a wedge in the southeast (lower right) portion of this cuboid anomaly and gradually decreases in magnitude towards the northwest and closer to the surface. At the surface, this magnetic susceptibility high coincides both with DMF1 and the Middle to Late Permian Klondike Schist (PK2), which are in thrust contact.

The magnetic susceptibility high in section C-C' (Figures 13 and 14) extends from 6.50 to $8.50 \mathrm{~km}$ distance, is wedge-shaped, with thickness ranging from $\sim 250$ to $\sim 750 \mathrm{~m}$ from northwest to southeast. This anomaly is found directly below the surface and coincides on the surface with the Carboniferous to Permian Slide Mountain Terrane (CPSM4), the Lower Cretaceous Indian River Formation (IKIR), the Upper Cretaceous Carmacks Group (uKC1), and the DMF1.

In section D-D' (Figures 13 and 14), one magnetic susceptibility high is $\sim 500$ m-wide hemispherical at $800 \mathrm{~m}$ below the surface and centered at $5.60 \mathrm{~km}$ distance. Another magnetic susceptibility high to the southeast, is located between 7.0 and $10.75 \mathrm{~km}$ distance, which from $\sim 8.0 \mathrm{~km}$ distance is asymmetrically divided into two to the northwest and to the southeast. The northwest portion of the second magnetic susceptibility high is thinner at $200 \mathrm{~m}$ thickness, while the southeast portion is wedge shaped (similar to the magnetic susceptibility high observed in $\left(-C^{\prime}\right.$ ), and ranges from $\sim 200$ to $\sim 700 \mathrm{~m}$ in thickness. The hemispherical anomaly is located beneath DMF3. However, it is uncertain what unit it is associated with at depth.

To its northwest, section E-E' (Figures 13 and 14) exhibits two small (<200 m wide), ovoid magnetic susceptibility highs centered at 0.15 and $1.9 \mathrm{~km}$ distance and located $\sim 150$ and $\sim 250 \mathrm{~m}$ beneath the surface, respectively. These coincide with DMF3. To its southeast, section E-E' exhibits dispersed magnetic susceptibility highs that can be grouped into two elevation levels. The shallower magnetic susceptibility highs to the southeast, which lie at $250 \mathrm{~m}$ below the surface and are located between 8.0 and $10.5 \mathrm{~km}$ distance, coincide with PK2, MgSR, and IKIR at the surface. These appear to be thinner than the magnetic susceptibility highs directly to the southwest (section D-D') and to the northeast (section

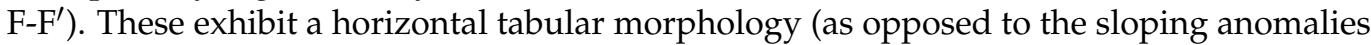
associated mostly with the volcanic flows of uKC1 and the DMF3. Lastly, these exhibit lateral thinning/taper. The deeper magnetic susceptibility high to the southeast, located between 10.5 and $12.5 \mathrm{~km}$ distance, lies $~ 500 \mathrm{~m}$ beneath the outcrops of $\mathrm{uKC} 1$ and the DMF1. It is an isolated $\sim 2 \mathrm{~km}$-long horizontal semi-ovoid at the base of this section.

Section F-F' (Figures 13 and 14) exhibits an anomaly pattern roughly similar to the one found towards the southeast of section D-D'. A $\sim 4.0 \mathrm{~km}$-long magnetic susceptibility high to the southeast of section $\mathrm{F}_{-} \mathrm{F}^{\prime}$ is located between 6.8 and $10.80 \mathrm{~km}$ distance and from $\sim 7.6 \mathrm{~km}$ distance is asymmetrically divided into twoto the northwest and to the southeast. The northwest portion of this magnetic susceptibility high is $\sim 250 \mathrm{~m}$-thick and much shorter at $\sim 700 \mathrm{~m}$ long, while the southeast portion is wedged and ranges from 100 to $700 \mathrm{~m}$ in thickness (roughly similar to the magnetic susceptibility high observed in $\mathrm{D}^{-\mathrm{D}^{\prime}}$ ). This anomaly is found beneath the outcrops of $\mathrm{uKC} 1$.

In section G-G' (Figures 13 and 14), one magnetic susceptibility high has a 100 m-wide vertical semi-ovoid shape that is directly below the surface, located between 0.70 and $0.80 \mathrm{~km}$ distance, and centered at $0.70 \mathrm{~km}$ distance. A second magnetic susceptibility high to the southeast, which has a hemispherical shape, is $1.5 \mathrm{~km}$ below the surface and is located 
between 2.25 and $3.0 \mathrm{~km}$ distance. A third magnetic susceptibility high is located between 4.80 and $8.4 \mathrm{~km}$ distance, which from $\sim 6.3 \mathrm{~km}$ distance is divided into two asymmetrically to the northwest and to the southeast. The northwest portion of the second magnetic susceptibility high is thinner at $\sim 150 \mathrm{~m}$ thickness, while the southeast portion is wedge shaped (similar to the magnetic susceptibility high observed in $C-C^{\prime}$ ), and ranges from $\sim 200$ to $\sim 600 \mathrm{~m}$ in thickness. The semi-ovoid and hemispherical magnetic susceptibility highs to the northwest are located beneath the DMF3.

In section $\mathrm{H}-\mathrm{H}^{\prime}$ (Figures 13 and 14), the first magnetic susceptibility high exhibits a right-skewed downward-facing, elliptic-paraboloid shape, which is $500 \mathrm{~m}$ below the surface and is located between 2.2 and $2.9 \mathrm{~km}$ distance. This first magnetic susceptibility high can be correlated on the surface to DMF3. The second magnetic susceptibility high is horizontal and exhibits a tabular morphology. It is $200 \mathrm{~m}$-thick and $\sim 1.40 \mathrm{~km}$-long. It is located directly below the surface, between 2.90 and $4.25 \mathrm{~km}$ distance and can be correlated on the surface to PK2. Lastly, the third magnetic susceptibility high extends from $4.4 \mathrm{~km}$ and $6.0 \mathrm{~km}$ distance, is wedge-shaped, and has a thickness ranging from $\sim 350$ and $\sim 750 \mathrm{~m}$ from northwest to southeast. This magnetic susceptibility high is found directly below the surface and coincides with the surface with uKC1.

Section I-I' (Figures 13 and 14) exhibits two wedge-shaped magnetic susceptibility highs, which together span the entire length of the section. Both of these wedge-shaped magnetic susceptibility highs have their tips facing the center at around $2.25 \mathrm{~km}$ distance, are found directly beneath the surface, and range in thickness between 200 and $650 \mathrm{~m}$ in thickness. These magnetic susceptibility highs coincide mostly with uKC1 and PK2, and to a minor degree, DMF3.

\subsection{Gold Assay Data}

Analysis of gold assay data from Flow Metal Corp's drillhole samples in the Sixtymile mining district (i.e., drillholes SM21-09 to SM21-12, DDH-10-01 to DDH-10-03, DDH 11-15, and DDH 11-18; see Supplementary Table S2, and Figures S1 and S3) revealed the presence of possibly two E-to-SE-dipping gold-bearing horizons (Figure 15). The eastern mineralized horizon has an approximate thickness of $50 \mathrm{~m}$, while the western horizon's thickness is less certain since the drillhole depths are limited at this location. The gold-bearing horizons are hosted by schists with different mineral compositions (muscovite-quartz schist, graphite schist, muscovite schist, quartz-chlorite schist, biotite-chlorite quartz schist, and muscovite-chlorite schist, e.g., Supplementary Figures S10-S15). Alteration is dominated by silicification (DDH-10-1 to 3; DDH-11-15 and 18; SM21-09-12), with minor argillization (DDH-11-18), sericitization (DDH-10-01, DDH-11-18), and chloritization (DDH10-01). Visible gold is present and is commonly accompanied by sulfide minerals such as arsenopyrite and pyrite, and less commonly by galena. 


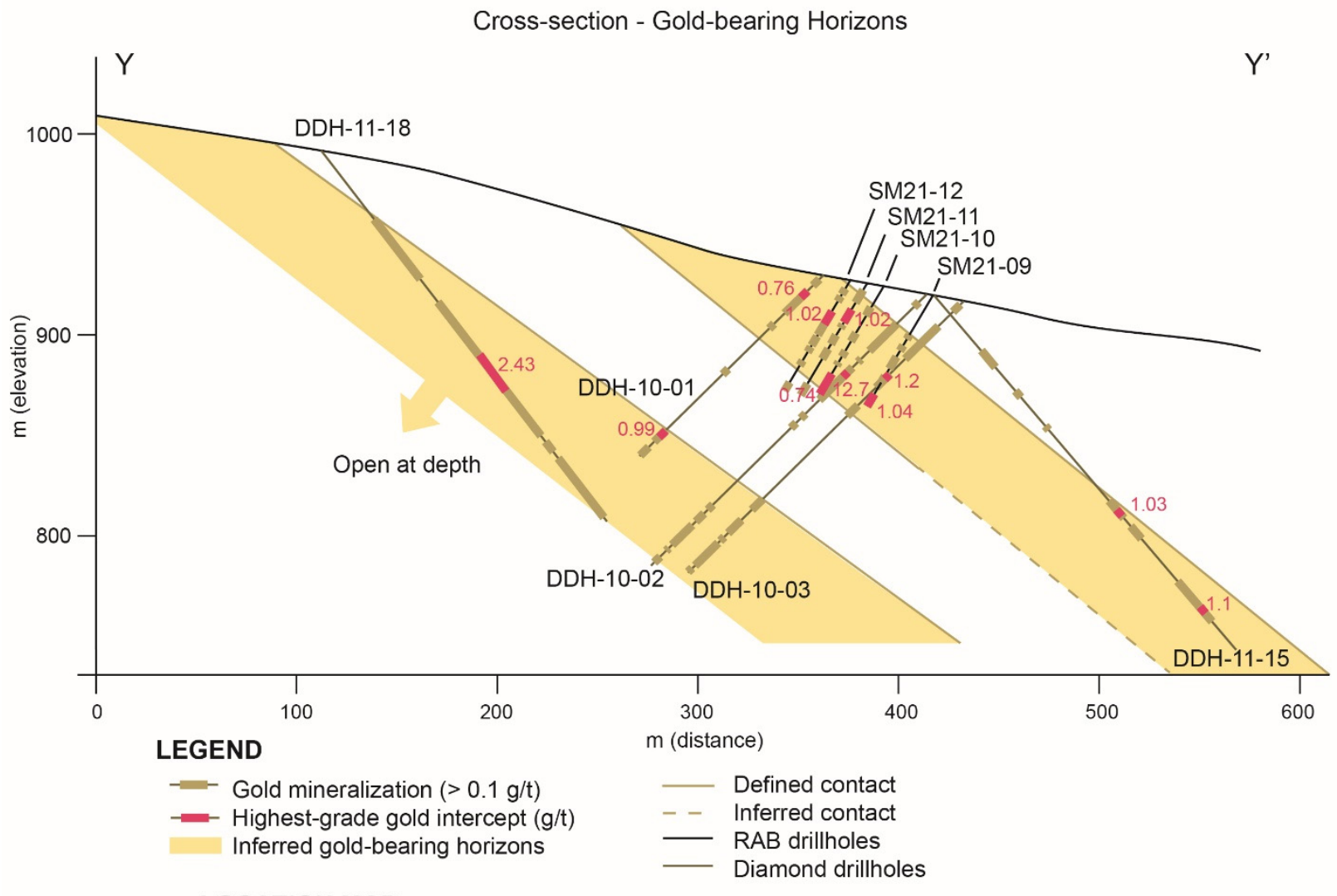

LOCATION MAP

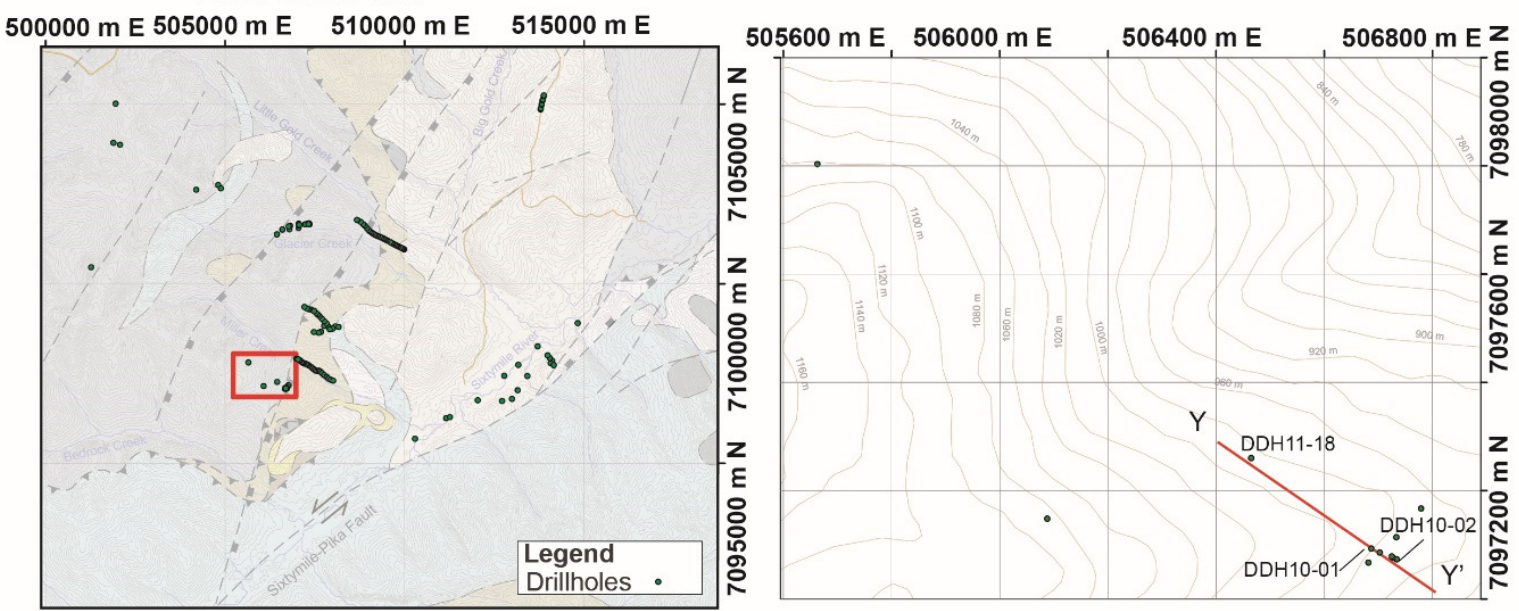

Figure 15. Gold-bearing horizons inferred from drilling. 'Gold mineralization' corresponds to gold $(\mathrm{Au})$ assay values above $0.1 \mathrm{~g} / \mathrm{t}$ Au. A 'highest-grade gold intercept $(\mathrm{g} / \mathrm{t})^{\prime}$ is the highest assay value measured within a drillhole interval ( $\sim 5 \mathrm{~m}$ or thicker) that exhibits 'gold mineralization.' Coincident magnetic susceptibility values are shown in Figure 16. See Supplementary Table S2, and Figures S1 and S3 for details of drillholes SM21-09 to SM21-12, DDH-10-01 to DDH-10-03, DDH 11-15, and DDH 11-18.

\section{Discussions}

\subsection{Structural Measurements}

The structures observed in the Sixtymile district share similar characteristics with the structures that MacKenzie et al. (2008) [5] documented in the Klondike district, which they relate to several major deformation stages that they originally interpreted (D1, D2, D3, D4, 
and D5). In this section, we reconcile our observations within the structural framework of MacKenzie et al. (2008) [5].

The foliation documented in this study resembles the foliation formed during the D1 and D2 deformation events, that is defined in MacKenzie et al. (2008) [5] as alignment of micas and is also associated with syn-metamorphic (?) quartz veins (Figure 4). Postmetamorphic folding, which likely occurred as early as the D3 deformation event, occurs throughout the Sixtymile district, as illustrated by the NW-SE-trending cross-section through the Miller Creek (Figure 8). This type of folding was also observed regionally from Mortensen's (1996) [43] mapping of both the Klondike and Sixtymile areas.

There is generally a weaker correlation between fractures and veins compared to between foliation and veins. Some fractures with certain orientations and in certain locations bear veins (Figures 5 and 9), but most do not, which could be a consequence of a combination of factors, such as the timing of the formation of the fractures, the timing and duration of mineralization and permeability, etc. [45,46]. In the Glacier Creek, where there is a more obvious association between fractures and veins, the fracture orientations, which are mostly NW-SE- and NE-SW-striking and near-vertical appear to be consistent with the dominant orientations of mineralized D4 structures in the Klondike district [5] (Figures 5 and 9). Veins that are found at high angles to foliation were also documented in cores (e.g., Supplementary Figures S12 and S13). Slade (2020) [47] documented similar high angle veins with visible gold, arsenopyrite, and sphalerite, which he associated with D4 and D5 structures.

The documentation of the top-to-the-NW oblique reverse fault outcrop is the first of its kind in the area and has a vergence opposite to the top-to-the-SE 'Thrust Zone,' which was described by Hulstein (2011) [44] mainly using geophysical data. Conversely, this reverse faulting geometry is kinematically consistent with the series of SE-dipping reverse faults which are possibly related either to thrust stacking of the basement units in the area (D3) or the later fault-fold deformation stage (D4). The association of quartz veins with this oblique reverse fault is consistent with MacKenzie et al.'s (2008) [5] observations of D4 structures in the Klondike District, which exert a strong control on local- and regional-scale post/syn-D4 deformation vein emplacement. However, the fact that it cuts through $\mathrm{uKC} 1$ is evidence of thrusting that is much younger than D4 thrust faults. Mesothermal mineralization along D3/D4 (and younger) reverse faults probably take place via fault-valve rupture (Sibson et al., 1988) [48]. While the exact kinematics of the strike-slip fault we identified remains uncertain (i.e., left- or right-lateral), the high angle that this strike-slip fault forms with respect to the NE-SW-striking left-lateral Sixtymile-Pika Fault, suggest that it could be an antithetic (?) Riedel shear. By association with the Late Cretaceous Sixtymile-Pika Fault, which is coeval to D5 deformation, this strike slip fault could possibly belong to D5 deformation event. Furthermore, while the D5 deformation event is characterized as mainly involving extension, expressed as normal faulting, the existence of such Cretaceous (?) strike-slip features suggest that these structures may have accommodated regional extension, which is separate from possible local extension that occurred at bends and step-overs.

\subsection{Magnetic Susceptibility}

We present plausible explanations for the occurrence of magnetic susceptibility anomalies by interpreting these in their geologic context. We interpret particular anomalies as possibly representing certain lithologies, structures, or zones of hydrothermal alteration associated with mineralization.

The extensive surficial anomalies that typically exhibit a taper in cross-sectional view and coincide spatially with $\mathrm{uKC1}$ and DMF1, are interpreted here mainly as thick volcanic successions. Anomalies interpreted as volcanic successions include those located towards the southeast between 6.50 and $8.50 \mathrm{~km}$ distance of section C-C $C^{\prime}, 7.0$ and $10.75 \mathrm{~km}$ distance of section D-D', 6.8 and $10.80 \mathrm{~km}$ distance of section F-F', 4.8 and $8.4 \mathrm{~km}$ distance of section G- $\mathrm{G}^{\prime}, 4.40$ and $6.0 \mathrm{~km}$ distance of section $\mathrm{H}-\mathrm{H}^{\prime}$, and 0.0 and $3.6 \mathrm{~km}$ distance of section $\mathrm{I}-\mathrm{I}^{\prime}$ 
(Figure 14). While the wedge-shaped anomaly to the northwest of I-I' (Figure 14) is found beneath DMF3 and PK2, considering the uncertainty in mapping of units at this scale and the proximity of both anomalies in this section to $\mathrm{uKC} 1$, these anomalies are most likely associated with the thick volcanic succession of $\mathrm{uKC1}$. While $\mathrm{uKC1}$ is widely known as an exceptionally extensive and thick volcanic succession [31], the range of thickness of this unit is uncertain. Therefore, these thick wedge-shaped anomalies can be attributed either to a really thick volcanic unit that drapes the original topography and forms thick deposits in basins or to a volcanic unit with mostly uniform thickness that is underlain by an intrusive body.

The anomalies that are mostly isolated and deeper, and are found beneath geologic formations that are not usually associated with high magnetic susceptibility, are interpreted here as possible intrusive bodies and/or zones of hydrothermal alteration associated with mineralization (e.g., alteration assemblages including magnetite or pyrrhotite). Anomalies interpreted as intrusive bodies and/or zones of mineralization include the following: the ovoid/ellipse-shaped anomalies located between 2.75 and $3.70 \mathrm{~km}$ distance of section $\mathrm{A}-\mathrm{A}^{\prime}$; the semi-circular anomaly between 5.5 and $5.8 \mathrm{~km}$ distance of section $\mathrm{D}^{-\mathrm{D}^{\prime}}$; the shallow ovoid anomalies centered at 0.15 and $1.9 \mathrm{~km}$ distance of section $\mathrm{E}^{\prime} \mathrm{E}^{\prime}$; the broad, deep anomaly between 10.5 and $12.5 \mathrm{~km}$ distance, which could possibly be a batholith; the semiellipse and semi-circular anomalies centered at 0.75 and $2.6 \mathrm{~km}$, respectively, along section G-G'; vertical semi-ellipse and semi-circular anomalies located between 0.70 and $0.80 \mathrm{~km}$ distance and between 2.25 and $3.0 \mathrm{~km}$ distance, respectively, along section $\mathrm{H}_{-} \mathrm{H}^{\prime}$ (Figure 14).

Some anomalies in the Sixtymile district are more open to several interpretations than others, as a consequence of deviations from the expected associations between geology and occurrence of magnetic susceptibilities. For instance, in Section B-B' ${ }^{\prime}$, the anomaly that is located between 5.30 and $6.30 \mathrm{~km}$ distance is found partially beneath DMF3, which is generally associated with low magnetic susceptibility values. In the simplest case, it could represent an intrusion/ore body through DMF3 and the adjacent PK2. Alternatively, if this anomaly is related to PK2, then this could possibly imply a wider distribution of this unit in the subsurface (e.g., related to west-verging blind thrusts beneath DMF3). Another example is the lack of an anomaly closer to the surface between 11.0 and $13.0 \mathrm{~km}$ distance of Section E-E' (Figure 14), which is usually associated with uKC1 and DMF1. This could possibly be due to the dominance of felsic/intermediate composition volcanic flows within $\mathrm{uKC1}$, and intermediate metamorphic rocks within DMF1 along this section.

The magnetic susceptibility values measured from surface samples (Supplementary Table S1), are on the lower end of the range of values recovered from the inversion. This could be due to the fact that our measurements of magnetic susceptibility sample only a small fraction of the total amount of cores retrieved from diamond drilling, which are limited in spatial distribution and extent to begin with. Despite this narrower range of relatively lower magnetic susceptibility values, and the fact that there is considerable variation in measurements from the same lithology, we observed that higher magnetic susceptibility values can be observed among samples belonging to certain formations. In particular, chloritemica shists (e.g., DDH11-02; Supplementary Figures S1, S2, S19 and S20 and Table S1), and andesites (e.g., DDH11-05 and DDH11-08; Figures S1, S2, S26, S27, S31 and S32 and Table S1), which belong to $\mathrm{uKC1}$, were characterized by the highest magnetic susceptibility values. It is worth noting, though, that a previous study by Mira Geoscience (2014) [19] reports the presence of much higher magnetic susceptibility values (i.e., up to $124.0 \times 10^{-3}$ SI) than what we measured from samples belonging to $\mathrm{uKC} 1$, which is consistent with our modeling results. Consistent with both our field measurements and modeling, another study by Szumigala et al. (2002) [49] reports much lower values of $0.03-0.25 \times 10^{-3}$ SI for the Klondike Schist (PK2) and Nasina Schist DMF3.

Analyses of drillhole cross-sections (Figure 16) and the geology vis à vis the distribution of magnetic susceptibility values (Figures 13, 14 and 17) provide further understanding of the association between geology and anomalies. It is worth noting that cross-sections through the schists of DMF3 and PK2 (Figure 16) show high gold (Au) assay values de- 
spite being associated with low magnetic susceptibility. On the other hand, cross-sections through the predominantly volcanic uKC1 (Figures 13 and 14), which display relatively higher magnetic susceptibility values, have not yet been associated with gold (Au) assay values that are comparable to those mostly found in the schists of DMF3 and PK2. Additionally, a comparison of the geologic cross-section in this study to the proximal section E-E' (Figure 17) does not seem to reveal any compelling evidence of structural controls on anomalies, at least from this section of the study area.

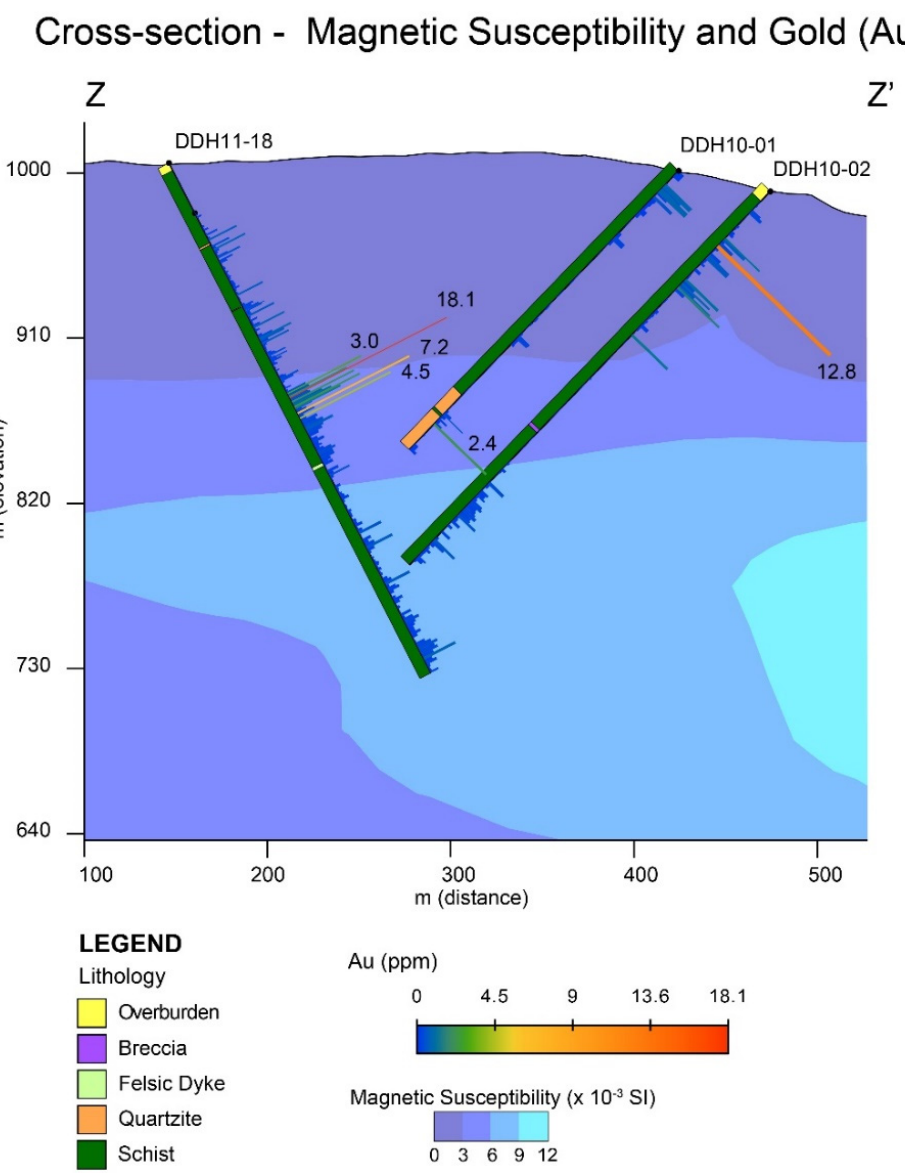

LOCATION MAP

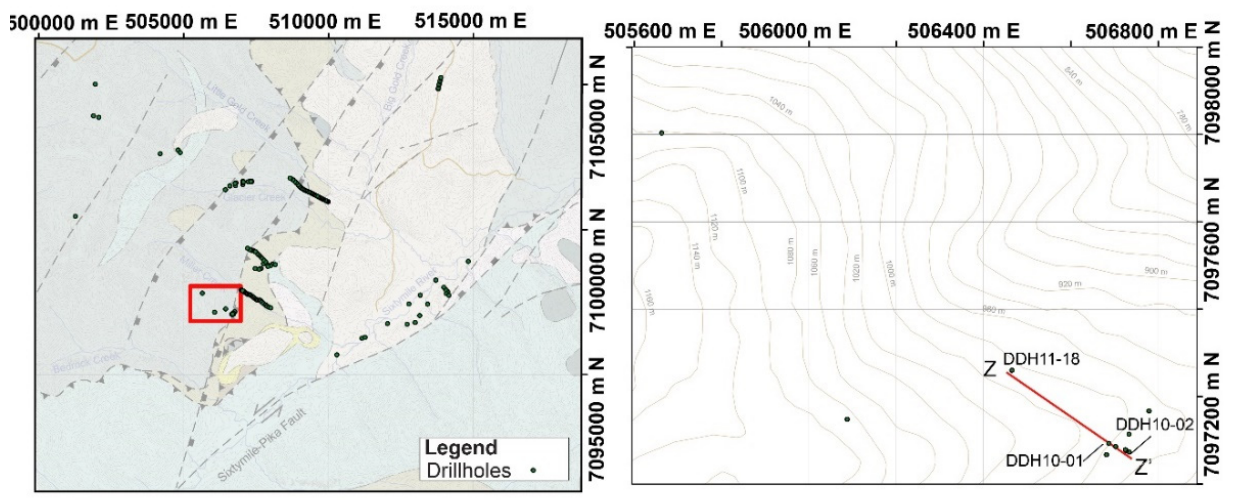

Figure 16. Drillholes on the ridge to the SW of the Miller Creek area showing gold ( $\mathrm{Au})$ assay values and schists that coincide with low magnetic susceptibility values. The length of bins on the bar graphs that are superimposed on the drillholes are proportional to the measured Gold ( $\mathrm{Au}$ ) grade at the corresponding depth. The assay values are also indicated by the color scale. 


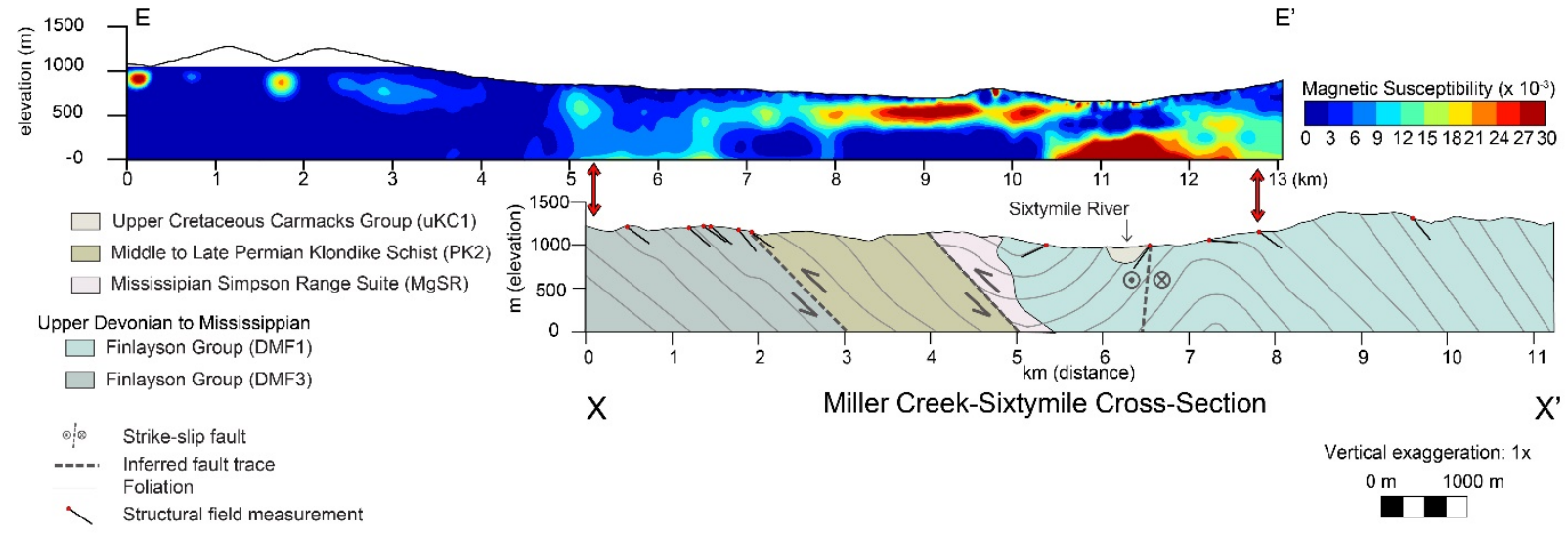

Figure 17. Comparison between the magnetic susceptibility cross-section E-E' and the Miller CreekSixtymile River cross-section.

While we interpret the anomalies mainly to distinguish volcanic units from the metamorphic units in the Sixtymile district and to identify possible intrusive bodies or mineralized zones, there are factors that could possibly complicate these interpretations, such as possible variations in protolith types in the metamorphic units, the presence of igneous units with distinct petrogenesis, or the degree and type of alteration by hydrothermal fluids that affect both the metamorphic and volcanic units [33]. Some areas which register low magnetic susceptibilities may originally be units that typically have high magnetic susceptibility but may have been altered through the introduction of hydrothermal fluids, such as towards the southeast of section E-E' (Figures 14 and 17), which coincides with the DMF1. On the other hand, some of the areas that register high magnetic susceptibilities may have simply been enriched with ferromagnetic minerals and may not necessarily represent gold-bearing deposits. These issues are however, not unique to this work and are inherent limitations on many potential-field-based studies. Nonetheless, further analysis is required to draw definitive conclusions about relationships among geology, magnetic susceptibility values, and metal assays.

\subsection{Gold-Bearing Horizons}

Two E-to-SE-dipping gold-bearing horizons that are inferred from gold assay data (Figure 15), together with our other field structural measurements, possibly suggest strong control of E-dipping structures on the mineralization in the Sixtymile district. The goldbearing horizons (Figure 15) appear to be related to sets of veins parallel to the E-dipping host rock foliation. While MacKenzie et al. (2008) [5] claim that there is no evidence for gold enrichment in foliation-parallel quartz veins, the presence of these inferred gold-bearing horizons suggest otherwise. One possibility is that these gold-bearing, foliation-parallel veins were coeval with the D1 and/or D2 structures. Another possibility is that these veins are related to D4 deformation stage or younger structures, which may or may not have involved fault slip along pre-existing zones of weakness, such as foliation planes. Despite the lack of direct evidence to suggest that these horizons are related to faulting, this explanation remains a likely possibility given their proximity to mapped thrusts (Figures 2 and 15). The Sixtymile-Pika Fault zone, which encompasses the study area, exerts a structural control on Late Cretaceous magmatism and hydrothermal mineralization, which is probably the source of the observed lode Au horizons [22].

\section{Conclusions}

Our structural measurements in the Glacier Creek, Miller Creek, Bedrock Creek, and Sixtymile River areas show varying degrees of correlation among orientations of foliation, fractures, and veins. In most localities, veins are found both along or parallel to foliation, and at high angles to foliation. With exception to NE-SW- and NW-SE-striking fractures 
in Glacier Creek, there is generally a weaker correlation between fractures and veins compared to between foliation and veins. Documentation of oblique reverse faulting associated with quartz veins has provided evidence of a much younger compressional deformation than previously recognized (possibly closer to the end of the Late Cretaceous). Another significant finding is the presence of E-dipping gold-bearing horizons that are either related to sets of veins parallel to the D1 and/or D2 foliation of the host rock or to the D4 deformation stage or younger reverse/thrust faults. Three-dimensional-magnetic susceptibility highs are preferentially associated with the Upper Cretaceous Carmacks Group ( $\mathrm{uKC} 1$ ), and to a lesser degree, the Upper Devonian to Mississippian Finlayson Group (DMF1). However, some anomalies appear within units comprising lithologies that are not usually associated with high magnetic susceptibility, such as the Upper Devonian to Mississippian Finlayson Group (DMF3) and the Middle to Late Permian Klondike Schist (PK2), and therefore could likely represent either intrusive bodies or zones of mineralization. Higher resolution inversions are required to accurately determine the geometry, dimensions, lithology, and composition of these anomalies. Additional diamond drilling in areas with rather high magnetic susceptibility anomalies, especially in locations that reflect much higher model-derived values than our core-derived magnetic susceptibility values could help clarify the nature of these anomalies. More detailed documentation and radiometric dating of structures associated with high assay values (e.g., the E-dipping gold-bearing horizons), through trenching and follow-up drilling, could further constrain the trends and ages of structures that have the potential of producing economic deposits in the area.

Supplementary Materials: The following supporting information can be downloaded at: https: //www.mdpi.com/article/10.3390/min12030291/s1, Text S1: Upper Devonian to Mississippian Finlayson Group carbonaceous metasedimentary rocks (DMF3); Text S2: Middle to Late Permian Klondike Schist (PK2); Text S3: Upper Devonian to Mississippian Finlayson Group intermediate to mafic volcanic and volcaniclastic rocks, and fine-grained amphibolite and greenstone (DMF1); Text S4: Upper Cretaceous Carmacks Group; Figure S1: Drillhole location map; Figure S2: Drillhole location map A; Figure S3: Drillhole location map B; Figure S4: Drillhole location map C; Figure S5: Drillhole location map D; Figure S6: Drillhole location map E; Figure S7: Drillhole location map F; Figure S8: Drillhole location map G; Figure S9: Drillhole location map H; Figure S10: DDH-11-18 core samples; Figure S11: DDH-11-15 core samples; Figure S12: DDH-11-15 core samples; Figure S13: Thin section view of DDH-11-15-1; Figure S14: Thin section view of DDH-11-15-2; Figure S15: Thin section view of DDH-11-15-3; Figure S16: DDH-11-20 core samples; Figure S17: Thin section view of DDH-11-20-1; Figure S18: DDH-11-01 core samples; Figure S19: DDH-11-02 core samples; Figure S20: Thin section view of DDH-11-02-1; Figure S21: DDH-11-10 core samples; Figure S22: Thin section view of DDH-11-10-1; Figure S23: DDH-11-03 core samples; Figure S24: Thin section view of DDH-11-03-1; Figure S25: Thin section view of DDH-11-03-2; Figure S26: DDH-11-05 core samples; Figure S27: DDH-11-05 core samples; Figure S28: DDH-11-07 core samples; Figure S29: Thin section view of DDH-11-07-1; Figure S30: Thin section view of DDH-11-07-2; Figure S31: DDH-11-08 core samples; Figure S32: Thin section view of DDH-11-08-1; Figure S33: DDH-11-16 core samples; Figure S34: Thin section view of DDH-11-16-1; Figure S35: DDH-11-17 core samples; Figure S36: Thin section view of DDH-11-17-1; Table S1: Magnetic susceptibility drillhole measurements; Table S2: Selected Gold Assay results in the Sixtymile district.

Author Contributions: Conceptualization, J.R., A.L.P. and J.V.; methodology, J.R., A.L.P., M.G., H.S.; software, J.R., M.G., H.S.; validation, J.R., A.L.P., M.G., J.V. and H.S.; formal analysis, J.R., A.L.P., M.G., J.V. and H.S.; investigation, J.R., A.L.P., M.G., J.V., H.S.; resources, J.R., A.L.P. and J.V.; data curation, J.R. and A.L.P.; writing—original draft preparation, J.R.; writing—review and editing, J.R., A.L.P., M.G., J.V. and H.S.; visualization, J.R. and H.S.; supervision, A.L.P. and J.V.; project administration, J.R., A.L.P. and J.V.; funding acquisition, J.R., A.L.P. and J.V. All authors have read and agreed to the published version of the manuscript.

Funding: This research was funded by a Natural Sciences and Engineering Research Council (NSERC) Discovery Grant (RGPIN-2021-04011) and a Mitacs Accelerate internship (IT24819) sponsored by Flow Metals Corp. (Vancouver, British Columbia) through Mr. Scott Sheldon (CEO, Flow Metals Corp.). 
Data Availability Statement: The data presented in this study are openly available in the open-access Zenodo repository at https: / doi.org/10.5281/zenodo.5768247, and in the Supplementary Material.

Acknowledgments: Jeremy Rimando's postdoctoral fellowship at McMaster University was gratefully funded in part by a Mitacs Accelerate internship (IT24819) sponsored by Flow Metals Corp. (Vancouver, British Columbia) through Scott Sheldon (CEO, Flow Metals Corp.), and by a Natural Sciences and Engineering Research Council (NSERC) Discovery Grant (RGPIN-2021-04011) awarded to Alexander Peace. The authors would like to acknowledge Manas Toews and Justin Emberley of the Yukon Geological Survey for facilitating access to key diamond drill core samples at the H.S. Bostock Core Library in Whitehorse City. The authors are also grateful to the McDougall family (Mike, Kim, and Hannah) for hosting them at their camp in the Sixtymile mining district. We also acknowledge that our work in the Sixtymile mining district was conducted on Tr'ondek Hwech'in First Nation traditional territory.

Conflicts of Interest: The authors declare no conflict of interest.

\section{References}

1. Canada Department of the Interior. The Yukon Territory, Its History and Resources; Government Printing Bureau: Ottawa, ON, Canada, 1909. Available online: https:/ / electriccanadian.com/history/yukon/yukonhistory.pdf (accessed on 16 February 2021).

2. LeBarge, W.P. Yukon Placer Database 2007: Geology and Mining Activity of Placer Occurrences; Yukon Geological Survey: Whitehorse, YT, Canada, 2007.

3. Hamilton, T.D. Late Cenozoic glaciation of Alaska. In The Geology of North America. The Geology of Alaska; Plafker, G., Berg, H.C., Eds.; Geological Society of America: Boulder, CO, USA, 1994; Volume G-I, pp. 813-844. [CrossRef]

4. Lowey, G.W.; Emond, D.S.; Weston, L.H. Glaciation, gravel and gold in the Fifty Mile Creek area, west-central Yukon. In Yukon Exploration and Geology 1999; Emond, D.S., Weston, L.H., Eds.; Exploration and Geological Services Division, Yukon, Indian and Northern Affairs Canada: Whitehorse, YT, Canada, 2000; pp. 199-209. Available online: https://emrlibrary.gov.yk.ca/ygs/yeg/ 1999/1999_p199-210.pdf (accessed on 18 February 2021).

5. MacKenzie, D.J.; Craw, D.; Mortensen, J. Structural controls on orogenic gold mineralisation in the Klondike goldfield, Canada. Mineralium Deposita 2008, 43, 435-448. [CrossRef]

6. Boyle, R.W. The Geochemistry of gold and its deposits. In Bulletin, Geological Survey of Canada; Energy, Mines and Resources Canada: Ottawa, ON, Canada, 1979; Volume 280, p. 584. Available online: https://publications.gc.ca/site/eng/9.817728 /publication.html (accessed on 17 February 2021).

7. Henley, R.W.; Adams, J. On the evolution of giant gold placers. In Transactions of the Institution for Mining and Metallurgy; Institution of Mining and Metallurgy: London, UK, 1979; Volume 88, pp. B41-B51.

8. Allan, M.M.; Mortensen, J.K.; Hart, C.J.R.; Bailey, L.A.; Sanchez, M.G.; Ciolkiewicz, W.; McKenzie, G.; Creaser, R. Magmatic and metallogenic framework of west-central Yukon and eastern Alaska. In Tectonics, Metallogeny, and Discovery: The North American Cordillera and Similar Accretionary Settings; Society of Economic Geologists Special Publication: Littleton, CO, USA, 2013; Volume 17, pp. 111-168. [CrossRef]

9. MacLean, T.A. Lode Mining in Yukon: Investigation of Quartz Deposits in the Klondike Division (No. 222); Government Printing Bureau: Ottawa, ON, Canada, 1914. Available online: https://emrlibrary.gov.yk.ca/gsc/separate-reports/222-lode-mining-inyukon-an-investigation-of-quartz-deposits-in-the-klondike-division-1914.pdf (accessed on 17 February 2021).

10. Rushton, R.W.; Nesbitt, B.E.; Muehlenbachs, K.; Mortensen, J.K. A fluid inclusion and stable isotope study of Au quartz veins in the Klondike District, Yukon Territory, Canada; a section through a mesothermal vein system. Econ. Geol. 1993, 88, 647-678. [CrossRef]

11. Freeman, S. In Search of the Motherlode: Why Yukon is Experiencing a 21st Century Gold Rush. Financial Post. Available online: https: / / financialpost.com/commodities/mining/in-search-of-the-motherlode-why-yukon-is-experiencing-a-new-goldrush (accessed on 1 August 2021).

12. Naumov, V.; Barge, W.; Kovin, O. A new insight into origin of the Yukon placer gold. In Proceedings of the 45th International October Conference on Mining and Metallurgy, Bor, Serbia, 16-19 October 2013; Volume 4, p. 4.

13. Chapman, R.J.; Mortensen, J.K.; LeBarge, W.P. Styles of lode gold mineralization contributing to the placers of the Indian River and Black Hills Creek, Yukon Territory, Canada as deduced from microchemical characterization of placer gold grains. Mineralium Deposita 2011, 46, 881-903. [CrossRef]

14. Knight, J.B.; Mortensen, J.K.; Morison, S.R. Lode and placer gold composition in the Klondike District, Yukon Territory, Canada; implications for the nature and genesis of Klondike placer and lode gold deposits. Econ. Geol. 1999, 94, 649-664. [CrossRef]

15. Mortensen, J.K.; Chapman, R.; LeBarge, W.; Crawford, E. Compositional studies of placer and lode gold from western Yukon: Implications for lode sources. In Yukon Exploration and Geology 2005; Emond, D.S., Bradshaw, G.D., Lewis, L.L., Weston, L.S., Eds.; Yukon Geological Survey: Whitehorse, YT, Canada, 2005; pp. 247-255. Available online: https://emrlibrary.gov.yk.ca/ygs/yeg/ 2005/2005_p247-256.pdf (accessed on 1 September 2021). 
16. MacKenzie, D.J.; Craw, D.; Mortensen, J.K.; Liverton, T. Structure of schist in the vicinity of the Klondike goldfield, Yukon. In Yukon Exploration and Geology 2006; Emond, D.S., Lewis, L.L., Weston, L.H., Eds.; Yukon Geological Survey: Whitehorse, YT, Canada, 2007; pp. 197-212. Available online: https://emrlibrary.gov.yk.ca/ygs/yeg/2006/2006_p197-212.pdf (accessed on 17 February 2021).

17. Bond, J.D.; Sanborn, P.T. Morphology and Geochemistry of Soils Formed on Colluviated Weathered Bedrock: Case Studies from Unglaciated Upland Slopes in West-Central Yukon; Yukon Geological Survey: Whitehorse, YT, Canada, 2006. Available online: https: / ygsftp. gov.yk.ca/publications/openfile/2006/of2006_19.pdf (accessed on 17 February 2021).

18. Mortensen, J.K.; Chapman, R.; LeBarge, W.; Jackson, L.; Edmund, D.S.; Lewis, L.L.; Bradshaw, G.D. Application of placer and lode gold geochemistry to gold exploration in western Yukon. In Yukon Exploration and Geology, 2004; Exploration and Geological Services Division, Yukon, Indian and Northern Affairs Canada: Whitehorse, YT, Canada, 2004; pp. 205-212. Available online: https:/ / emrlibrary.gov.yk.ca/ygs/yeg/2004/2004_p205-212.pdf (accessed on 1 September 2021).

19. Mira Geoscience. Geologically-Constrained Inversion of Magnetic and Gravity Data Over Parts of the Yukon-Tanana Terrane and Whitehorse Trough; Miscellaneous Report MR-10; Yukon Geological Survey: Whitehorse, YT, Canada, 2014; pp. 1-85. Available online: https:/ / emrlibrary.gov.yk.ca/ygs/MR/MR-10/MR-10_WT-YTT_Modelling.pdf (accessed on 1 December 2021).

20. Welford, J.K.; Clowes, R.M.; Ellis, R.M.; Spence, G.D.; Asudeh, I.; Hajnal, Z. Lithospheric structure across the craton-Cordilleran transition of northeastern British Columbia. Can. J. Earth Sci. 2001, 38, 1169-1189. [CrossRef]

21. Hayward, N. Geophysical investigation and reconstruction of lithospheric structure and its control on geology, structure, and mineralization in the Cordillera of northern Canada and eastern Alaska. Tectonics 2015, 34, 2165-2189. [CrossRef]

22. Sánchez, M.G.; Allan, M.M.; Hart, C.J.; Mortensen, J.K. Extracting ore-deposit-controlling structures from aeromagnetic, gravimetric, topographic, and regional geologic data in western Yukon and eastern Alaska. Interpretation 2014, 2, SJ75-SJ102. [CrossRef]

23. Yukon Geological Survey. Yukon Digital Bedrock Geology. Available online: https://data.geology.gov.yk.ca/Compilation/3 (accessed on 12 September 2021).

24. Goldfarb, R.J.; Hart, C.; Miller, M.; Miller, L.; Farmer, G.L.; Groves, D.I. The Tintina gold belt-A global perspective. In The Tintina Gold Belt: Concepts, Exploration, and Discoveries; British Columbia and Yukon Chamber of Mines: Vancouver, BC, Canada, 2000; Volume 2, pp. 5-34.

25. Bailey, L.A. Late Jurassic Fault-Hosted Gold Mineralization at the Golden Saddle Deposit, White Gold District, Yukon Territory. Master's Thesis, The University of British Columbia, Vancouver, BC, Canada, 2013. Available online: http://hdl.handle.net/2429 /44517 (accessed on 17 February 2021).

26. Naibert, T.J. Structural geology observations in the northeast Tanacross map area. In Northeast Tanacross Geologic Mapping Project, Alaska; Wypych, A., Ed.; Alaska Division of Geological \& Geophysical Surveys: Fairbanks, AK, USA, 2020; pp. 43-52. [CrossRef]

27. Sánchez, M.G.; Allan, M.M.; Hart, C.J.; Mortensen, J. Orogen-perpendicular magnetic segmentation of the western Yukon and eastern Alaska cordilleran hinterland: Implications for structural control of mineralization. In Yukon Exploration and Geology 2012; MacFarlane, K.E., Nordling, M.G., Sack, P.J., Eds.; Yukon Geological Survey: Whitehorse, YT, Canada, 2013 ; pp. 133-146. Available online: https://ygsftp.gov.yk.ca/publications/yeg/yeg12/YEG/9_Sanchez_etal.pdf (accessed on 17 February 2021).

28. Allan, M.M.; Mortensen, J.K.; Sánchez, M.G.; Hart, C.J.R. Structural and geochronological controls on Late Cretaceous porphyry andepithermal mineralization of the orogen-normal Sixtymile-Pika fault system, Yukon and Alaska. In preparation.

29. Mortensen, J.K. Geology and U-Pb geochronology of the Klondike District, west-central Yukon Territory. Can. J. Earth Sci. 1990, 27, 903-914. [CrossRef]

30. Lowey, G.W.; Hills, L.V. Lithofacies, petrography and environments of deposition, Tantalus Formation (Lower Cretaceous) Indian River area, west-central Yukon. Bull. Can. Petrol. Geol. 1988, 36, 296-310. [CrossRef]

31. Johnston, S.T.; Wynne, P.J.; Francis, D.; Hart, C.J.R.; Enkin, R.J.; Engebretson, D.C. Yellowstone in Yukon: The late Cretaceous Carmacks group. Geology 1996, 24, 997-1000. [CrossRef]

32. Telford, W.M.; Geldart, L.P.; Sheriff, R.E. Applied Geophysics, 2nd ed.; Cambridge University Press: Cambridge, UK, 1990. [CrossRef]

33. Clark, D.A.; Emerson, J.B. Notes on rock magnetization characteristics in applied geophysical studies. Explor. Geophys. 1991, 22, 547-555. [CrossRef]

34. Nabighian, M.N.; Grauch, V.J.S.; Hansen, R.O.; LaFehr, T.R.; Li, Y.; Peirce, J.W.; Phillips, J.; Ruder, M.E. The historical development of the magnetic method in exploration. Geophysics 2005, 70, 33ND-61ND. [CrossRef]

35. Geng, M.; Ali, M.Y.; Fairhead, J.D.; Bouzidi, Y.; Barkat, B. Morphology of the basement and Hormuz salt distribution in offshore Abu Dhabi from constrained 3-D inversion of gravity and magnetic data. Tectonophysics 2020, 791, 228563. [CrossRef]

36. Geng, M.; Welford, J.K.; Farquharson, C.G.; Peace, A.L.; Hu, X. 3-D joint inversion of airborne gravity gradiometry and magnetic data using a probabilistic method. Geophys. J. Int. 2020, 223, 301-322. [CrossRef]

37. Geng, M.; Welford, J.K.; Farquharson, C.G.; Hu, X. Gravity modeling for crustal-scale models of rifted continental margins using a constrained 3D inversion method. Geophysics 2019, 84, G25-G39. [CrossRef]

38. Geng, M.; Welford, J.K.; Farquharson, C.G.; Peace, A.L. 3D inversion of airborne gravity gradiometry data for the Budgell Harbour Stock, Newfoundland: A case history using a probabilistic approach. Geophysics 2019, 84, B269-B284. [CrossRef]

39. Peace, A.L.; Welford, J.K.; Geng, M.; Sandeman, H.; Gaetz, B.D.; Ryan, S.S. Rift-related magmatism on magma-poor margins: Structural and potential-field analyses of the Mesozoic Notre Dame Bay intrusions, Newfoundland, Canada and their link to North Atlantic Opening. Tectonophysics 2018, 745, 24-45. [CrossRef] 
40. Tarantola, A. Inverse Problem Theory and Methods for Model Parameter Estimation; Society for Industrial and Applied Mathematics (SIAM): Philadelphia, PA, USA, 2005. [CrossRef]

41. Poon, J. Airborne Geophysical Survey Report, 60 Mile Property Block A, C, and D (Internal Radius Gold Inc. Report); Precision Geosurveys Inc.: Langley, BC, Canada, 2010.

42. Li, Y.; Oldenburg, D.W. 3-D inversion of magnetic data. Geophysics 1996, 61, 394-408. [CrossRef]

43. Mortensen, J.K. Geological Compilation Maps of the Northern Stewart River Map Area, Klondike and Sixtymile Districts:(115N/15, 16; 1150/13, 14 and Parts of 115O/15, 16), 1: 50000 Scale; Exploration and Geological Services, Indian and Northern Affairs Canada: Whitehorse, YT, Canada, 1996. Available online: https://ygsftp.gov.yk.ca/publications/openfile/1996/of1996_1(g).pdf (accessed on 17 February 2021).

44. Hulstein, R. Report on the Sixty Mile Property 2011 Geophysical Survey \& Diamond Drilling. Dawson Mining District, Yukon Territory; NTS: 116C/02 \& 115N/15. Available online: https:/ /yma.gov.yk.ca/096256/096256.pdf (accessed on 1 September 2021).

45. Lonergan, L.; Wilkinson, J.; McCaffrey, K. Fractures, fluid flow and mineralization: An introduction. Geol. Soc. London, Spec. Publ. 1999, 155, 1-6. [CrossRef]

46. Sekine, R.; Izawa, E.; Watanabe, K. Timing of fracture formation and duration of mineralization at the Hishikari deposit, Southern Kyushu, Japan. Resour. Geol. 2002, 52, 395-404. [CrossRef]

47. Slade, H. Geological Report: Sixtymile Claim 2020. Flow Metals: Vancouver, BC, Canada. 2020, Unpublished Work.

48. Sibson, R.H.; Robert, F.; Poulsen, K.H. High-angle reverse faults, fluid-pressure cycling, and mesothermal gold-quartz deposits. Geology 1988, 16, 551-555. [CrossRef]

49. Szumigala, D.J.; Werdon, R.J.; Athey, M.B.; Stevens, J.E.; Flynn, D.S.P.; Clautice, R.L.; Craw, K.H. Geologic Map of the Eagle A-1 Quadrangle, Fortymile Mining District: Alaska Division of Geological \& Geophysical Surveys Preliminary Interpretive Report 2002-1A, 1 Sheet, Scale 1:63,360. Available online: https:/ / doi.org/10.14509/2863 (accessed on 1 September 2021). 